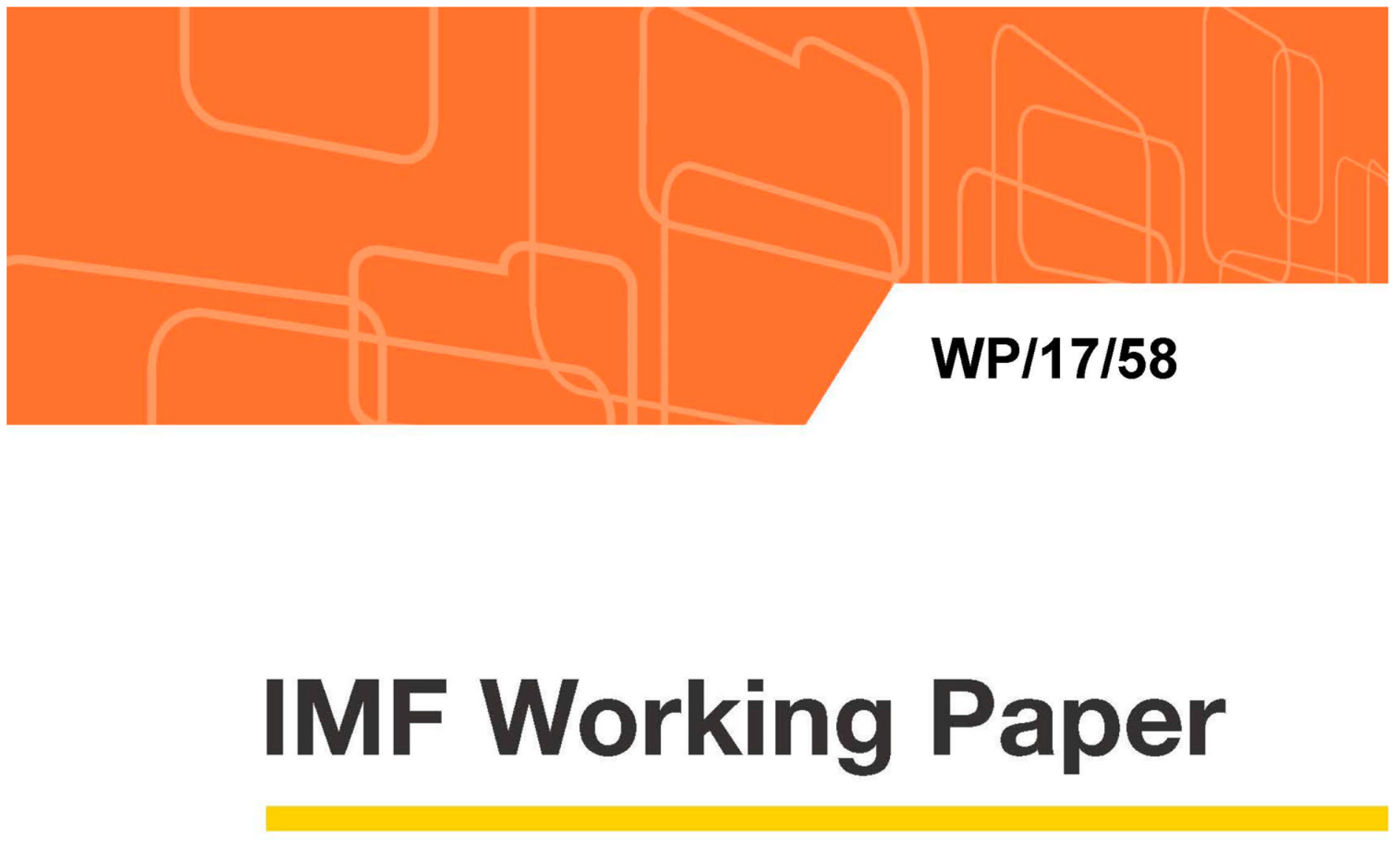

\title{
Exchange Rates and Trade: A Disconnect?
}

by Daniel Leigh, Weicheng Lian, Marcos Poplawski-Ribeiro,

Rachel Szymanski, Viktor Tsyrennikov, and Hong Yang

IMF Working Papers describe research in progress by the author(s) and are published to elicit comments and to encourage debate. The views expressed in IMF Working Papers are those of the author(s) and do not necessarily represent the views of the IMF, its Executive Board, or IMF management. 


\section{WP/17/58}

\section{IMF Working Paper}

\section{Exchange Rates and Trade: A Disconnect?}

by Daniel Leigh, Weicheng Lian, Marcos Poplawski-Ribeiro,

Rachel Szymanski, Viktor Tsyrennikov, and Hong Yang

IMF Working Papers describe research in progress by the author(s) and are published to elicit comments and to encourage debate. The views expressed in IMF Working Papers are those of the author(s) and do not necessarily represent the views of the IMF, its Executive Board, or IMF management.

I N T E R N A T I O N A L M O NETAR Y FU N D 


\title{
IMF Working Paper
}

Research Department

\author{
Exchange Rates and Trade: A Disconnect?* \\ Prepared by Daniel Leigh, Weicheng Lian, Marcos Poplawski-Ribeiro, \\ Rachel Szymanski, Viktor Tsyrennikov, and Hong Yang \\ Authorized for distribution by Oya Celasun
}

March 2017

\begin{abstract}
IMF Working Papers describe research in progress by the author(s) and are published to elicit comments and to encourage debate. The views expressed in IMF Working Papers are those of the author(s) and do not necessarily represent the views of the IMF, its Executive Board, or IMF management.
\end{abstract}

\begin{abstract}
We examine the stability and strength of the relationship between exchange rates and trade over time using three alternative approaches, mitigating the endogeneity of the relation. We find that both exchange rate pass-through and the price elasticity of trade volumes are largely stable over time. Economic slack and financial conditions affect the relationship, but there is limited evidence that participation in global value chains has significantly changed the exchange rate-trade relationship over time.
\end{abstract}

JEL Classification Numbers: F14, F31, F41

Keywords: exchange rate disconnect, global trade, exchange rates and trade

Author's E-Mail Address: dleigh@imf.org; wlian@imf.org; mpoplawskiribeiro@imf.org; viktor.tsyrennikov@gmail.com; rszymanski@imf.org; hyang2@imf.org

\footnotetext{
${ }^{*}$ We are grateful for comments by Swarnali Ahmed, JaeBin Ahn, Aqib Aslam, Rudolfs Bems, Olivier Blanchard, Matthieu Bussière, Benjamin Carton, Oya Celasun, Romain Duval, Davide Furceri, Bertrand Gruss, Thomas Helbling, Gee Hee Hong, Zsoka Koczan, Gian Maria Milesi-Ferretti, Nicolas Magud, Maurice Obstfeld, Pau Rabanal, Hector Torres, and the participants in seminars at the IMF Research Department and in the IMF-SNB conference on "Exchange Rates and External Adjustment". Olivia Ma provided excellent research assistance.
} 


\section{INTRODUCTION}

Recent exchange rate movements have been unusually large. The U.S. dollar has appreciated by more than 10 percent in real effective terms since mid-2014, the euro has depreciated by more than 10 percent since early 2014, and the yen has lost more than 30 percent of its value since mid-2012. ${ }^{1}$ The recent time paths of these currencies and their historic ranges are shown in Figure 1. Such movements, although not unprecedented, are well outside the normal fluctuation ranges of these currencies. ${ }^{2}$ The uneven recovery from the crisis, the deployment of unconventional monetary policies, and, more recently, the depreciation of the British pound following the vote in the United Kingdom in favor of leaving the European Union are among the factors contributing to this phenomenon.

Even for emerging market and developing economies (EMDEs), whose currencies typically fluctuate more than those of advanced economies (AEs), the recent movements have been unusually large. The yuan and the rupee have appreciated substantially while the Brazilian real and South African rand depreciated by more than 50 percent from mid-2012 to the end of 2015. These currency movements have potentially large implications for trade competitiveness and the design of optimal policies. There is, however, no consensus on whether these changes imply large redistributions of trade flows in favor of depreciating currencies as they did in the past.

Standard theoretical models predict that currency changes pass through into consumer prices. A domestic depreciation reduces export prices in a foreign currency and increases import prices in the domestic currency, which leads to more exports and less imports. This is the expenditure-switching effect of a currency depreciation (Obstfeld and Rogoff 2007). Basing his analysis on the above reasoning, Krugman $(2015,2016)$ predicts that the recent exchange rate movements will have a strong effect on trade. Bussière et al. (2016) argue that exchange rate changes can play an important role in addressing global trade imbalances by estimating trade elasticities for systemically important economies. Others argue that there is a disconnect between exchange rates and trade. Recent studies by Ollivaud, Rusticelli, and Schwellnus (2015) and Ahmed, Appendino, and Ruta (2016) suggest that the increased participation in global value chains (GVCs) is a source of the apparent disconnect.

Claims of an exchange rate-trade disconnect, also referred to as "elasticity pessimism" (Machlup 1950), gained popularity in the 1980s after the U.S. dollar's depreciation initially failed to promote U.S. trade, and the yen's appreciation following the 1985 Plaza Accord had little initial effect on Japanese exports. Nonetheless, the U.S.-Japan trade balance later adjusted in line with the predictions of conventional models (Krugman 1991). The main

\footnotetext{
${ }^{1}$ Effective exchange rate refers to the exchange rate weighted by trade flows of a country's partners.

${ }^{2}$ Normal fluctuation range refers to the interval of exchange rate change that occurs with a 90 percent probability.
} 
question, therefore, is whether the current situation is different and trade has become less connected to exchange rates, possibly reflecting the changes in the organization of world trade since the trade liberalization that began in the 1990s.

Whether exchange rates and trade are disconnected is important for the formulation of economic policies. Such a disconnect could make exchange rates less effective in absorbing external shocks and weaken monetary policy by reducing its effect on trade balance. A disconnect also could slow down the resolution of global imbalances.

The focus of this paper is on the stability of the relationship between exchange rates and trade flows over time. Endogeneity of the studied relation is the most important challenge that we mitigate in several ways. First, we analyze separately the relationship between exchange rates and trade prices (exchange rate pass-through), and that between trade prices and trade volume (price elasticity of trade volume). This allows us to control for foreign and domestic demands in the regression specifications to be in line with theory, mitigating omitted variable biases. In particular, we control for unit labor costs in exchange rate passthrough equations to reduce the bias caused by the Balassa-Samuelson-Baumol effect. ${ }^{3}$

Second, we analyze the stability of the relationship between exports and exchange rates using large depreciation episodes, which are less subject to reverse causality from trade to exchange rates. Third, we analyze the relationship using sectoral data, as the exposure to exchange rate movements varies across sectors due to different composition of their trading partners, and sector-level trade is less likely to have a reverse effect on exchange rates. Sector-level data also provides an opportunity to evaluate the effects of GVCs on the exchange rate-trade relationship by exploiting variations in GVC involvement at the countrysector level.

Our study is the most extensive to date in terms of country coverage. We estimate trade elasticities for 60-88 AEs and EMDEs for the period 1980-2014, depending on the specific exercises. Our dataset goes beyond core AEs typically examined in related studies, which is warranted by the growing importance of EMDEs in world trade. ${ }^{4}$ Given noisy trade data, individual trade elasticities are typically estimated imprecisely at the macroeconomic level. Our broad country coverage reduces the risk that the stability result may be driven by idiosyncratic noise.

\footnotetext{
${ }^{3}$ This downward bias on the pass-through elasticity from the real effective exchange rate to trade prices reflects rising distribution and retail costs, owing to the increase in the costs of labor and rent internationally (BalassaSamuelson effects) and domestically (Baumol effects) over time (Frankel, Parsley, and Wei 2012).

${ }^{4}$ Much of the literature focuses on AEs. Notable exceptions include Bussière, Delle Chiaie, and Peltonen (2014), which estimates trade price equations for 40 economies, whereas Morin and Schwellnus (2014), estimate trade elasticities for 41 economies (most of them OECD members).
} 
The three alternative analyses yield similar conclusions and indicate the robustness of our results. ${ }^{5}$ We find that trade elasticities are generally stable over time. We estimate that a 10 percent real effective depreciation in an economy's currency is associated, on average, with a 1.5 percent of GDP increase in real net exports, with substantial cross-country variation around this average. Most of the response of trade to exchange rate movements materializes within the first year.

Our analysis does not find compelling evidence that GVC participation has weakened the exchange rate-trade relationship. It is worth noting that even a decline in trade elasticities could be consistent with greater economic significance of exchange rate movements. This is due to the process of trade globalization that resulted in increased shares of exports and imports in GDP. Global value chain-related trade has generally increased only gradually through the decades and appears to have slowed in recent years (Constantinescu et al. 2015). The bulk of global trade still consists of conventional trade, with the foreign value content of exports currently averaging only about 25 percent across economies. These facts make it difficult to estimate precisely the effect of GVC participation on the relationship. In contrast, we find that tighter financial conditions and lower economic slack reduce the response of export volume to exchange rates.

Our analysis also shows that the choice of deflator for trade volume significantly affects the results. ${ }^{6}$ The exchange rate pass-through into consumer prices is much weaker than into border prices. Moreover, the CPI reflects prices of many non-traded goods and services, which do not relate to the cost structure of exports. Both of these factors underscore that the CPI-deflated trade volume is a biased measure of the true volume, and using it in econometric analysis may lead to spurious results.

The remainder of this paper is structured as follows. Section II describes our estimates of trade elasticities at the macroeconomic level. Section III investigates large currency depreciation episodes, and Section IV performs the analysis based on sectoral data. Section V concludes and discusses the main policy implications of our findings.

\footnotetext{
${ }^{5}$ We base our conclusions on the pooled estimates. But individual country estimates are also sensible despite being much noisier. In particular, exchange rate pass-through coefficients and trade elasticities estimated for individual economies mostly fall within their theoretical bounds. That is, exchange pass-through coefficients are between 0 and 1, trade price elasticities are negative, and the two elasticities satisfy the Marshall-Lerner condition.

${ }^{6}$ For more details, see also Appendix B.
} 


\section{Estimating Aggregate Trade Elasticities}

This section estimates aggregate trade elasticities: the relationship between exchange rate movements and relative export and import prices (exchange rate pass-through), and that between relative prices and trade volumes (price elasticity of trade volume). Estimating exchange rate pass-through and price elasticity of trade volume separately avoids the potential bias caused by a misspecification of trade equations.

The exchange rate pass-through equation can be motivated from the pricing-to-market literature (Krugman 1986; Feenstra, Gagnon, and Knetter 1996; Campa and Goldberg, 2005; Atkeson and Burstein 2008; Burstein and Gopinath 2014; Feenstra and others 2014). In this framework, exporting firms maximize profits by choosing export prices, while taking into account the demand for their products and their competitors' prices; currency movements may not be passed into export prices relative to competitors' prices one-for-one. The exchange rate pass-through equation of exports takes the following form:

$$
\frac{e P^{X}}{P^{*}}=S\left(\frac{U L C}{P}, \frac{e P}{P^{*}}\right),
$$

where $e$ is the nominal effective exchange rate (NEER); $P^{\mathrm{X}}$ is the price of exports in domestic currency; $P^{*}$ is the foreign price level; $P$ is the domestic price level; $U L C$ is the nominal unit labor cost, so that $U L C / P$ denotes the real unit labor cost; and $e P / P^{*}$ denotes the real effective exchange rate (REER). Controlling for the unit labor cost allows us to mitigate the bias caused by Balassa-Samuelson-Baumol effects - positive productivity shocks may lead to currency appreciation and lower export prices, confounding the exchange rate passthrough estimation.

The price elasticity of trade volume equation can be motivated from foreign consumers' optimal decisions, which lead export volumes to depend on export prices relative to competitors' prices and foreign demands. The price elasticity of export volume equation takes the following form:

$$
X=D\left(\frac{e P^{X}}{P^{*}}, Y^{*}\right)
$$

where $e P^{\mathrm{X}} / P^{*}$ is again the foreign currency relative export price; and $Y^{*}$ denotes the foreign demand. The standard practice in the literature is to measure $Y^{*}$ by trade-weighted foreign GDP. Given the difference across GDP components in import intensity (Bussière et al. 2013), we control for GDP components separately. The import price and volume equations can be 
derived analogously based on the observation that the price of each economy's imports is the price of its trading partners' exports expressed in domestic currency units. ${ }^{7}$

Estimating trade elasticities at the macroeconomic level has several caveats. First, the reverse causality from trade volume to trade prices can lead to a downward bias in the estimate of price elasticity of trade volume as explained in Orcutt (1950). Demands are not observed and preference shocks can lead to a shift in demands not captured by GDP or GDP components. Second, the heterogeneity of demand elasticities across different goods can lead to a downward bias, with estimated aggregate trade elasticities reflecting goods with lower elasticities (Imbs and Mejean 2015).

Because our paper is focused on the stability of trade elasticities, such biases become a concern only if the factors behind them exhibit trends. While directly exploring the trends of these factors is difficult, we examine the robustness of the stability results through two exercises: (i) an analysis of large currency depreciation episodes, ${ }^{8}$ where the reverse causality issue is less severe; and (ii) an analysis of trade elasticities at the sector level, where both the reverse causality and the aggregation bias are mitigated.

\section{A. Data}

The primary sources for our analysis are the IMF's World Economic Outlook (WEO) database, Information Notice System (INS), and Global Assumption and Global Economic Environment databases; the Organisation for Economic Co-operation and Development's OECD Economic Outlook; and the U.S. Bureau of Labor Statistics. The data on GVCs comes from the OECD-World Trade Organization's (WTO) Trade in Value Added (TiVA) database. Table 3 describes all indicators used in the paper and their sources. In addition, Table A1 in the Appendix lists all countries included in the analysis of GVCs.

The sample for this analysis includes 60 economies (23 AEs and 37 EMDEs). Depending on the data availability and the economy in question, the sample period starts between 1980 and 1989 and ends in 2014. ${ }^{9}$ When estimating trade elasticities for individual economies, the sample is restricted to those for which at least 25 years of annual data are available.

\footnotetext{
${ }^{7}$ The equations for imports are similar to (1) and (2). The import supply function is: $P^{M} / P=S\left(e P^{*} / P, Y\right)$; and the import demand function is: $M=D\left(P^{M} / P, Y\right)$.

${ }^{8}$ While we focus on large depreciations given their relevance in the current global economy conjuncture, our results are symmetric and robust to the identification of large appreciations (results not shown here, but available upon request).

${ }^{9}$ The sample further excludes a number of AEs with special circumstances: Hong Kong SAR and Singapore, given these economies' significant entrepôt activity; and Ireland, because of its special treatment of export sales (IMF, 2015a,b,c,d). To avoid unduly influencing the results with developments in small or very low-income economies, it excludes economies with fewer than 1 million inhabitants as of 2010, or with an average per capita income (at purchasing-power parity) of less than $\$ 3,000$ in 2014 prices.
} 
The main variables used in the analysis are defined as follows: the NEER and the consumer price index (CPI)-based REER are both taken from the IMF Information Notice System (INS). They are weighted averages of trading partner bilateral exchange rates, with the weights based on gross exports. We construct producer price index (PPI)-based REER, and trade-weighted foreign producer prices, using the trade weights from the INS. Whenever the sample size is not a concern, we use PPI-based variables to limit the potential bias caused by Balassa-Samuelson-Baumol effects. The unit labor costs data of OECD countries come from OECD Statistics. For non-OECD economies, we construct the unit labor cost as the total wage bill divided by real GDP, with the total wage bill ${ }^{10}$ and real GDP taken from the IMF's WEO database, Haver Analytics, the International Labor Organization, the IMF's International Financial Statistics, and the CEIC database.

\section{B. Empirical Strategy}

The benchmark models have the form of Autoregressive Distributed Lags (ARDL), which have been widely used in the literature (Bussière, Delle Chiaie, and Peltonen 2014, among others). The models are first estimated country-by-country to allow trade elasticities to differ across countries. We find large variations across countries in trade elasticities, which cannot be explained by country characteristics ${ }^{11}$ and some of which should be attributable to measurement errors in trade variables. Then, to study the stability of trade elasticities over time, we estimate rolling panel regressions that take the same form as the benchmark models.

The panel regression of the exchange rate pass-through to export prices in local currency takes the following form: ${ }^{12}$

$$
\Delta \ln \left(\frac{e P^{\mathrm{X}}}{P^{*}}\right)_{i t}=\mu_{i}+\tau_{t}+\rho \Delta \ln \left(\frac{e P^{\mathrm{X}}}{P^{*}}\right)_{i, t-1}+\sum_{j=0}^{2} \beta_{j} \Delta \ln \left(\frac{e P}{P^{*}}\right)_{i, t-j}+\sum_{j=0}^{2} \gamma_{j} \Delta \ln \left(\frac{U L C}{P}\right)_{i, t-j}+\varepsilon_{i t},
$$

where $\mu_{i}$ denotes country-fixed effects, $\tau_{t}$ denotes time fixed effects, and $\varepsilon_{i t}$ denotes the residuals. As we find little evidence that export prices adjust in response to exchange rate movements beyond two years, we include only two lags to account for possible delayed effects of exchange rate movements on export prices.

Without confusion, we abuse the notation by using the same symbols for the fixed effects and

\footnotetext{
${ }^{10}$ When unavailable, total wage bill data are constructed using the average wage rate and total employment.

11 The results are available upon request.

12 We conduct the panel cointegration tests proposed by Pedroni (2004) and find little evidence of cointegration among the variables.
} 
variable coefficients in the equation of the price elasticity of export volumes, which takes the following form:

$$
\Delta \ln X_{i t}=\mu_{i}+\tau_{t}+\rho \Delta \ln X_{i, t-1}+\sum_{j=0}^{2} \beta_{j} \Delta \ln \left(\frac{e P^{\mathrm{X}}}{P^{*}}\right)_{i, t-j}+\gamma \Delta \ln Y_{i t}^{*}+\lambda\left(\Delta \ln Y^{*} \times g f c\right)_{i t}+\varepsilon_{i t},
$$

where the coefficient of foreign demands $\Delta \ln Y_{i t}^{*}$ is allowed to change during the global financial crisis (defined as years 2008 and 2009) ${ }^{13}$.

The equation of exchange rate pass-through to import prices in local currency is:

$$
\Delta \ln \left(\frac{P^{\mathrm{M}}}{P}\right)_{i t}=\mu_{i}+\tau_{t}+\rho \Delta \ln \left(\frac{P^{\mathrm{M}}}{P}\right)_{i, t-1}+\sum_{j=0}^{2} \beta_{j} \Delta \ln \left(\frac{e P}{P^{*}}\right)_{i, t-j}+\Delta \ln Y_{i t}+\varepsilon_{i t},
$$

The equation of the price elasticity of import volumes is:

$\Delta \ln M_{i t}=\mu_{i}+\tau_{t}+\rho \Delta \ln M_{i, t-1}+\sum_{j=0}^{2} \beta_{j} \Delta \ln \left(\frac{e P}{P^{*}}\right)_{i, t-j}+\delta \Delta \ln X_{i t}+\gamma \Delta \ln D D_{i t}+\lambda(\Delta \ln Y \times g f c)_{i t}+\varepsilon_{i t}$, (6)

where we separately control for domestic demands - defined as the sum of real consumption and real investment, and real exports, to account for GDP components' differences in import intensity (Bussière et al. 2013, Morin and Schwellnus, 2014). In the analysis below, we focus on the long-term elasticity, defined as $\sum_{j=0}^{2} \beta_{j} /(1-\rho)$.

\section{Individual Economy Estimations}

We estimate trade elasticities country-by-country. Compared with the specification of the panel regressions (equations (3) - (6)), those of country-by-country regressions have two main differences. The first is that we replace time fixed effects with two variables: (i) a time trend, and (ii) a dummy of the global financial crisis. Controlling for the time trend takes into account country-specific productivity trends, which may confound the estimation due to Balassa-Samuelson-Baumol effects. We further control for global commodity prices in exchange rate pass-through equations.

The second difference is that for a large fraction of economies in our sample, a Dickey-Fuller cointegration test cannot reject that a cointegration relationship exists among the variables in

\footnotetext{
${ }^{13}$ See Bussière et al. (2013) for the argument.
} 
the regression equation. ${ }^{14}$ For these countries, we estimate the benchmark model in levels rather than in the ARDL form. The lagged dependent variables and lagged changes in other explanatory variables are excluded. Taking into account cointegration relationships enables us to estimate trade elasticities more efficiently.

Individual country estimates suggest that exchange rates and trade prices are connected on average in the sample. As presented in Figure 2, panel 1, almost all exchange rate passthrough coefficients fall into the interval of $[0,1] .{ }^{15}$ Table 4 computes the average of these coefficients and shows that a 10 percent exchange rate depreciation in real effective terms reduces export prices in local currency by 5.5 percent and increases import prices by 6.1 percent in the long-term, ${ }^{16}$ with most of the effects materializing within one year. These results suggest incomplete pass-through and are in line with previous studies. For example, Campa and Goldberg (2005) find that the average of the one-year import price pass-through coefficients for 23 OECD countries is 0.64 , which is comparable to our estimates of $0.58 .{ }^{17}$

The second panel of Figure 2 suggests that trade prices and trade volumes are connected. As the price elasticity of trade volume equations suffer from endogeneity issues, the results should be interpreted with caution - reverse causality and simultaneity issues may bias the size of the coefficient downward, while the measurement errors in trade prices may instead bias the size of the coefficients upward. ${ }^{18}$ Overall, we find that the estimated price elasticities of trade volume have expected negative signs. Their average, as reported in Table 4, suggests that a 10 percent increase in export and import prices reduces export and import volumes by about 3 percent in the long term. ${ }^{19}$ Most of these effects also materialize within one year.

${ }^{14}$ The share of economies for which there is no evidence of cointegration is 57 percent for export price equation (3), 50 percent for export volume equation (4), 56 percent for import price equation (5), and 54 percent for import volume equation (6), respectively.

${ }^{15}$ It is interesting to note that economies with stronger exchange rate pass-through to export prices in foreign currency tend to have weaker pass-through to domestic import prices, a pattern that also emerges from the findings of Bussière, Delle Chiaie, and Peltonen (2014).

${ }^{16}$ The corresponding response of export prices in domestic currency to a real effective currency depreciation of 10 percent would be a rise of 4.5 percent $(-10 \times(0.552-1))$.

${ }^{17}$ Table 1 of the paper.

${ }^{18}$ Trade volumes are measured as trade values divided by trade prices, and hence measurement error in trade prices may strengthen the negative correlation between the dependent variable and trade prices. Our estimated price elasticity of trade volume is far below one, suggesting that the measurement error is not large, as otherwise the price elasticity of trade volume should be biased towards one (Hillberry and Hummels 2013).

${ }^{19}$ While we present the results with the mean-group estimates in Table 4, the results using the panel estimation (pooled mean group) are similar (not shown here, but available upon request), indicating the robustness of the elasticities estimated. 
Our estimated price elasticities of trade volume appear low compared with those used in computable general equilibrium models of international trade policies (For example, Hillberry and Hummels 2013: Table 18.1). One explanation for this outcome is that the average trade elasticities are estimated across all types of episodes. ${ }^{20}$ Why does the average shock not induce strong adjustments in trade volume? Given retail price adjustment costs, delivery lags, and transaction-level economies of scale (Alessandria, Kaboski, and Midrigan 2010), it is likely that local retailers do not respond to noisy or transitory movements of import prices. The other explanation could be that the reverse causality plays a significant role, biasing downward estimated price elasticities of trade volume, although our results, reported in what follows, do not support this explanation. ${ }^{21,22}$

We further find that the Marshall-Lerner condition under incomplete pass-through ${ }^{23}$ holds for the average estimated elasticities, as reported in Table 4. Satisfying this condition suggests that not only are exchange rates and trade connected, but also that exchange rate depreciation leads to an improvement of nominal trade balances.

\section{Disconnect or Stability over Time?}

This section answers the main question of this paper: Has the relationship between exchange rates and trade remained stable over time? Or has the relationship weakened over time, and if so, what factors have been driving the change?

Previous studies have investigated the stability of trade elasticities without reaching a consensus. ${ }^{24}$ Several studies find evidence of changing trade elasticities for a single country or a subset of goods. For example, Otani, Shiratsuka, and Shirota (2001) find that the exchange rate pass-through to import prices declined in Japan in the 1990s, compared with

\footnotetext{
${ }^{20}$ Moreover, our average shock driving trade prices may also be different from shocks explored in other studies, for example, those during trade liberalization episodes.

${ }^{21}$ Preference shocks, which are hard to be measured or captured by GDP and its components, may drive trade prices and quantities in the same direction.

${ }^{22}$ Notice that we also find that the price elasticities of trade volume inferred from the large currency depreciation episodes in the next section are broadly similar to the numbers estimated here. Using a sector level analysis, we further find that industries with large shares in a country's export - whose foreign demand shifts are more likely to reversely affect exchange rates - have similar response of trade volumes to exchange rates compared with industries with small shares in a country's export.

${ }^{23}$ The condition differs from that under the complete-pass through and its derivation is available in Annex 3.3 of IMF (2015e).

${ }^{24}$ Goldstein and Kahn (1985) provide a comprehensive literature review on early studies.
} 
the 1980s; and Frankel, Parsley, and Wei (2012) find a downward trend in the pass-through to import prices for EMDEs in a study of eight commodities. ${ }^{25}$

Others contend that the instability results of these studies cannot be generalized. For example, Campa and Goldberg (2008) find that while the pass-through may have declined for import prices, the results are inconclusive for some types of goods and countries.

Most studies examine the exchange rate pass-through, with the important recent exception of Ahmed, Appendino, and Ruta (2016). ${ }^{26}$ Their paper analyzes exchange rate movements' effects on export volume, and finds that trade elasticities have declined in the recent decade. They attribute the results to the expansion of GVCs. We find, however, that their results depend critically on the use of CPIs as the deflator to construct export volumes from export values. The results are also sensitive to excluding outliers during high inflation episodes, as often-used approximate growth rates become inaccurate. ${ }^{27}$ These two critiques apply generally, and should be taken into account in every empirical analysis of trade elasticities.

We estimate equations (3) - (6) for successive 10-year rolling intervals for the global sample of countries ${ }^{28}$ - Asia and Europe, respectively. Table 2 lists the 88 AEs and EMDEs included in the analysis. ${ }^{29} \mathrm{We}$ analyze separately the subsamples of Asian and European economies because the expansion of GVCs in these two regions is stronger than elsewhere. If the expansion of GVCs has an economically meaningful impact, we can expect trade elasticities in these two regions to weaken over time.

We find little evidence that exchange rates and trade become disconnected over time. ${ }^{30}$ Figure 3 shows that our estimates have narrow confidence intervals and should allow us to detect the instability of trade elasticities if it is significant. Only the elasticity of imports for import prices shows some weakening toward the end of the sample in some regions. We do not regard this as evidence for a disconnect between exchange rates and trade, because the

\footnotetext{
${ }^{25}$ Gust, Leduc, and Vigfusson (2010) also provide evidence on the declining exchange rate pass-through to import prices over time, and shifts in the invoice currency chosen by economies are likely to play a role (see Gopinath, Itskhoki, and Rigobon 2010).

${ }^{26}$ See Ahmed, Appendino, and Ruta (2015) for the initial version of the paper.

${ }^{27}$ For more details, see Appendix B.

${ }^{28}$ The first 10-year interval used for estimation is 1990-1999, and the last is 2005-14.

${ }^{29} \mathrm{We}$ have more countries included here than with the individual country estimates, as the sample selection criterion here is less stringent: a country is included in the sample if it has 20 years of observation. Recall that the individual country estimations require 25 years. We relax this requirement, as a few countries are unlikely to distort the panel regression results. The gain in improving the efficiency of estimating the average trade elasticities by increasing the sample coverage can be significant.

${ }^{30}$ The finding of broad stability in exchange rate pass-through over time is consistent with the results of Bussière, Delle Chiaie, and Peltonen (2014), which test stability in exchange rate pass-through coefficients for the period 1990-2011 for 40 AEs and EMDEs.
} 
other three types of trade elasticities fail to exhibit the same pattern. It is also difficult to associate the decrease in import price elasticity with the development of GVCs, as GVCs experienced rapid expansion during the 1990s and reached a plateau during the mid-2000s. If participation in GVCs affects trade elasticities, we should see a decline in trade elasticity before the mid-2000s, which is not evident in Figure 3.

Structural break tests also rebut the hypothesis of a disconnect between exchange rates and trade. By separating the sample period into 1990-2001 and 2002-2014, Table 5 suggests that the trade elasticities in the two periods are similar. This is true even when the Chow test is restricted to economies with relatively large increases in GVC integration. The stability of trade elasticities is further obtained when we use samples employed elsewhere, for example, the 46 economies included in the analysis of Ahmed, Appendino, and Ruta (2016).

Figure 4 provides a perspective for understanding why GVC developments may not cause a disconnect between exchange rates and trade. The figure shows that the share of foreign value added (FVA) in world exports has risen from about 15 percent in the 1970s to about 25 percent in 2013. ${ }^{31}$ The pace of increasing GVC participation is slow and the bulk of global trade still consists of conventional trade, which helps explain why GVC participation may impact some goods and countries, but not trade elasticities at the macroeconomic level. ${ }^{32}$

Furthermore, other developments, including declining barriers to trade movements, may have strengthened the effects of exchange rates on exports and imports. It is worth recalling that that the macroeconomic relevance of trade elasticities depends on the shares of exports and imports in GDP, both of which have risen in recent decades, reflecting the process of trade globalization (Figure 5). On their own, the increases in these ratios imply larger effects of exchange rate movement on total imports and exports in percentage points of GDP.

Therefore, even a marginal decline in trade elasticities could, in the context of rising import and export ratios, be consistent with exchange rate movements having equally important or even greater macroeconomic implications for trade than before.

We demonstrate the stability of the price elasticity of trade volume by estimating equation (4) and (6), which involves two issues. The first is endogeneity. For example, preference shocks

\footnotetext{
${ }^{31}$ Figure 3 also suggests that for some economies, such as Hungary, Romania, Mexico, Thailand, and Ireland, the increase has been greater than 20 percentage points. Moreover, some evidence indicates that the rise of GVCs measured along this dimension has slowed in recent years. Indeed, Constantinescu, Mattoo, and Ruta (2015) find that the slower pace of GVC-expansion has contributed to the global trade slowdown observed since the global financial crisis.

32 The findings of the recent literature further suggest that, for economies that have become more deeply involved in GVCs, trade in GVC-related products may have become less strongly responsive to exchange rate changes. Cheng et al. (2016), for example, find that a real appreciation of a country's currency not only reduces its exports of domestic value added, but also lowers its imports of FVA (in contrast to the traditional rise in imports following currency appreciation). This latter result is consistent with the notion that GVC-related domestic and FVA are complements in production. In addition, the analysis finds that the magnitudes of import and export elasticities depend on the size of a country's contribution to GVCs - smaller domestic contribution of value added tends to dampen the response to exchange rate changes (see also IMF 2015a, 2015b, 2015c).
} 
may move trade volume and trade prices in the same direction and confound the estimation of elasticity. The second issue is the downward aggregation bias, which causes the price elasticity of trade volume to reflect a subset of goods that have low price elasticity (Imbs and Mejean 2015). While endogeneity has undetermined effects on the stability results, it can bias downward the trade elasticity. The downward aggregation bias may affect the stability results through changing the composition of countries' exports over time. The next two sections address these issues.

\section{Analysis of LARge CURRENCY DePRECIATION EPISODES}

This section focuses on the effects of large and sudden depreciations on exports. ${ }^{33}$ The advantage of analyzing large depreciation episodes is that exchange rate fluctuations in such cases are less likely to be driven by shocks from foreign demands, and hence more likely to be exogenous to export prices and volumes compared with other smaller depreciations. The exchange rate changes are likely to be the major factor influencing agents' decisions, as it is unlikely that foreign demand and preference shocks change abruptly and simultaneously. The demand curve should be relatively stable compared to the fundamentals of the economy in question, thus minimizing the bias in our implied price elasticities that measure the slope of the demand curve.

The exchange rate pass-through and price elasticity of trade volume of exports inferred from large currency depreciations, however, can differ from those inferred from other episodes. Exporters may respond more strongly to exchange rate movements, as they are more likely to overcome fixed adjustment costs of trade. But the exchange rate-trade link may not always be stronger during large currency depreciation episodes, because the financial intermediation can be severely depressed (Ahn, Amiti, and Weinstein 2011), especially for countries with a currency mismatch, dampening the responses of exports to exchange rate movements.

To reduce the bias due to an interruption of financial intermediation during large currency depreciation episodes, we exclude episodes with high inflation - those with annual inflation rates above 30 percent, and episodes associated with banking crises. If exchange rates and trade are disconnected over time, we should expect the responses of export prices and volumes to exchange rate movements during large depreciations episodes (that are not associated with banking crises) to decline over time.

Episodes of large currency depreciations have been explored by a seasoned literature from the 1990s and early 2000s (see Borensztein and De Gregorio 1989; Frankel and Rose 1996; Goldfajn and Valdés 1999; and Milesi-Ferretti and Razin 2002). These studies tend to find

\footnotetext{
${ }^{33}$ Our analysis focuses only on exports, given that various domestic developments that affect imports are likely to coincide with large exchange rate depreciations.
} 
large exchange rate movements have significant effects on CPI inflation and the current account. IMF (2015e) and De Gregorio (2016) revisit the methodology. ${ }^{34}$ De Gregorio (2016) examines episodes dating back to the early 1970s, and finds that the responses of CPI inflation and the current account to exchange rate movements are now more muted compared with the past. The important difference between our analysis and that of De Gregorio (2016) is that we study only part of the current account - focusing on exports - as imports and exchange rates can co-move due to third factors. Another difference in relation to the exchange rate pass-through is that we study changes in relative export prices rather than CPI.

\section{A. Methodology}

We identify large exchange rate depreciation episodes using two criteria. The first criterion identifies a large depreciation as an unusually sharp nominal depreciation of the currency visà-vis the U.S. dollar, with a numerical threshold set at the 90th percentile of all annual depreciations in the sample. The second criterion prevents the same large exchange rate depreciation episode from being captured more than once. It requires the change in the depreciation rate compared with the previous year to be unusually large (greater than the 90th percentile of all changes). Because exchange rates tend to be more volatile in EMDEs than in AEs, both thresholds are defined separately for the two groups. For the first criterion, the threshold for AEs is a depreciation of 13 percent vis-à-vis the dollar, whereas for EMDEs, the threshold is 20 percent. For the second criterion, the AE and EMDE thresholds are both about 13 percentage points.

To avoid potential bias in the inferred trade elasticities of exports, we study only episodes with annual inflation below 30 percent and not associated with banking crises. An episode is associated with a banking crisis if it occurred within three years of the crisis, based on an updated version of Laeven and Valencia's (2013) dataset. ${ }^{35}$

By applying our methodology to economies with data available on export volumes and prices during 1980-2014, we obtain 66 episodes of large currency depreciations. As reported in Table 6, about one-quarter (17) of these episodes occurred in AEs, ${ }^{36}$ which include the 1992 European Exchange Rate Mechanism crisis. The remaining episodes occurred in EMDEs and include the 1994 devaluation of the Chinese yuan and the large depreciation of the

\footnotetext{
34 Joy et al. (2015) also investigate currency and banking crises, but those authors are interested in the determinants of those crises rather than their effects on trade.

35 The episode in year $t$ is associated with a banking crisis if the banking crisis occurs in the interval $t-3$ to $t+3$.

36 The baseline results for the effects of large exchange rate depreciation episodes are compared with the results based on the following three alternative approaches: (i) local projection methods; (ii) thresholds based on real effective exchange rate depreciations; and (iii) using Laeven and Valencia's (2013) currency crisis episodes. In each case, the results are similar to the baseline results.
} 
Venezuelan bolívar in 2002. The episodes that satisfy our methodology are driven by concerns about misalignment of exchange rates with fundamentals rather than preference shocks to foreign demands. Some episodes cannot even be justified by concerns about fundamentals, with one example being the 44 percent depreciation of the New Zealand dollar against the U.S. dollar between 1997 and 2000, about which the Reserve Bank of New Zealand governor dismissed fundamentals as the cause. ${ }^{37}$

To infer trade elasticities, we define a dummy indicating the large exchange rate depreciation episode, and study its impact on exchange rates, export prices, and export volume separately. Our empirical strategy is similar to how Cerra and Saxena (2008) analyze banking crises, and Romer and Romer (2010) study fiscal shocks. The equations take the form of ARDL in first differences:

$$
\begin{gathered}
\Delta \ln \left(\frac{e P}{P^{*}}\right)_{i t}=\mu_{i}+\tau_{t}+\rho \Delta \ln \left(\frac{e P}{P^{*}}\right)_{i, t-1}+\sum_{j=0}^{2} \beta_{j} \text { shock }_{i, t-j}+\varepsilon_{i t}, \\
\Delta \ln \left(\frac{e P^{\mathrm{X}}}{P^{*}}\right)_{i t}=\mu_{i}+\tau_{t}+\rho \Delta \ln \left(\frac{e P^{\mathrm{X}}}{P^{*}}\right)_{i, t-1}^{2}+\sum_{j=0}^{2} \beta_{j} \operatorname{shock}_{i, t-j}+\sum_{j=0}^{2} \gamma_{j} \Delta \ln \left(\frac{U L C}{P}\right)_{i, t-j}+\varepsilon_{i t}, \\
\Delta \ln X_{i t}=\mu_{i}+\tau_{t}+\rho \Delta \ln X_{i, t-1}+\sum_{j=0}^{2} \beta_{j} \operatorname{shock}_{i, t-j}+\gamma \Delta \ln Y_{i t}^{*}+\varepsilon_{i t},
\end{gathered}
$$

where the subscript $i$ denotes the $i$-th country and the subscript $t$ denotes the $t$-th year; and shock is the dummy variable, indicating the occurrence of a large depreciation. We include country- and time dummies $\left(\mu_{i}\right.$ and $\left.\tau_{t}\right)$ to account for country fixed effects and common time trends, respectively. We cumulate the estimated lagged impacts of an episode of large exchange rate depreciation to obtain the dynamic impact on the level of export prices and export volumes.

We study the stability of trade elasticities here by splitting the sample into two equally by time and comparing the dynamic responses of the variables for these two period subsamples separately. Of the 66 large currency depreciation episodes in the sample, half (33) occurred in 1997 or earlier, and the other half occurred in more recent years. We compare inferred exchange rate pass-through to export prices and the price elasticity of export volume for those two subsamples.

\footnotetext{
${ }^{37}$ Donald Brash's speech "The fall of the New Zealand dollar - why has it happened, and what does it mean?" of October 5, 2000, addressed to the American Chamber of Commerce, can be accessed at http://www.bis.org/review/r001012b.pdf.
} 


\section{B. What Happens to Exports after a Large Exchange Rate Depreciation?}

We find that on average, large depreciations substantially boost exports. As shown by the solid line in Figure 6, panel 1, the real effective exchange rate declines on average 25 percent over five years during the identified depreciation episodes. Export prices in foreign currency fall by about 10 percent, with much of the adjustment occurring in the first year (solid line in Figure 6, mid-panel). The implied real exchange rate pass-through to export prices is thus about 0.4 , similar to the estimate based on the trade equations at macroeconomic level. The solid line in the right panel of Figure 6 shows that export volume increases gradually with the cumulated change of about 10 percent over five years. ${ }^{38}$ This response suggests an average price elasticity of exports of about 0.7 , which is higher than the elasticity of 0.3 estimated using trade equations at the macroeconomic level, and closer to the estimated value using sectoral data later. This higher estimated price elasticity is consistent with the idea that fixed costs preventing the adjustments of trade volumes during smaller depreciations are less important during large depreciation episodes. All results are statistically significant at conventional levels. ${ }^{39}$

\section{Large Depreciations and Disconnect}

To compare trade elasticities in the current context of dynamic trade and exchange rate responses to large currency depreciation events, we scale the impulse responses so that the first year's exchange rate responses to large currency depreciation events are the same in two subsamples. We then compare the movements of exchange rates after one year, and the changes in export prices and export volumes over time.

Figure 7 shows that exchange rate and export volume responses are very similar between the two subsamples. Although the export price responses seem to be weaker for the first two years after 1997 compared with before $1997,{ }^{40}$ the long-term changes are quite similar. These findings rebut the claim that exchange rate and trade are disconnected over time.

\footnotetext{
${ }^{38}$ Consistent with this result, Alessandria, Pratap, and Yue (2013) find that exports rise gradually following a large depreciation, based on data for 11 emerging market economies.

${ }^{39}$ These results are robust to alternative methodologies that estimate the impulse responses or identify large exchange rate movements. We experiment with using nominal exchange rates to define large depreciation episodes and studying the impulse responses using a local project method (Jordà 2005). Results are available upon request.

${ }^{40}$ We do not have a good explanation for this, which might reflect the different nature of the shocks driving large depreciations of exchange rates. However, when we conduct a rolling regression analysis for one-year and two-year exchange rate pass-through to export prices (results are available upon request), we do not find an evidence of disconnect over time.
} 


\section{The Role of Initial Conditions}

The analysis of large exchange rate depreciations allows us to investigate how initial economic conditions affect export responses to exchange rate movements. One hypothesis is that when there is more economic slack and a greater degree of spare capacity in the economy, there could be more scope for production and exports to expand following a rise in foreign demand associated with exchange rate depreciation. We proxy spare capacity by economic slack, and compute the median of the demeaned real GDP growth in the year preceding the episode for the 66 episodes ${ }^{41}$ Hence, an episode with initial slack is one in which demeaned real GDP growth is below the median for the 66 episodes (the median is near zero).

The results suggest that for the subsample of episodes with initial slack, the export gain is larger than in the full-sample baseline (by an additional 7 percentage points after five years, as suggested by long-dashed lines in Figure 8). ${ }^{42}$ Exchange rates also tend to depreciate more, and in a more persistent manner than in the baseline, arguably providing exporters with stronger incentives to cut export prices than in the baseline.

We also look at whether export boosts associated with a large exchange rate depreciation depend on the health of the exporting economy's financial sector. The hypothesis is that banking crises can depress exports by reducing the availability of credit needed to support export production, ${ }^{43}$ and the drop in credit availability can offset export gains due to the currency depreciation. To test this hypothesis, we apply the same criteria used in the previous subsections for exchange rate movements to define large currency depreciations, but only look at those associated with banking crises. With this new approach, we identify 57 new episodes distinct from those included in the baseline analysis. They include the large

\footnotetext{
41 The results are broadly similar when the definition of economic slack is based on the output gap in the year preceding the large exchange rate depreciation. For similar definitions of economic slack see Baum, PoplawskiRibeiro and Weber (2012).

42 To ease comparability of the results for the two groups, the estimated impulse responses are scaled to ensure that the first-year impact on the real exchange rate is exactly the same.

${ }^{43}$ Ronci (2004) analyzes the effect of constrained trade finance on trade flows in countries undergoing financial and balance of payments crises, and concludes that constrained trade finance depresses both export and import volumes in the short term. Dell'Ariccia, Detragiache, and Rajan (2005) and Iacovone and Zavacka (2009) find that banking crises have a detrimental effect on real activity in sectors more dependent on external finance, which includes export-oriented sectors. Kiendrebeogo (2013) investigates whether banking crises are associated with declines in bilateral exports, by estimating a gravity model using a sample of advanced economies and developing countries for the period 1988-2010. The results suggest that banking-crisis-hit countries experience lower levels of bilateral exports, with exports of manufactured goods falling particularly hard. More generally, for an analysis of the evolution of trade following large depreciations associated with financial crises, see IMF (2010).
} 
exchange rate depreciations in Finland and Sweden in 1993; Thailand and Korea in 19971998, respectively; Russia in 1998; Brazil in 1999; and Argentina in 2002. ${ }^{44}$

The results support our hypothesis. Figure 8 shows that the boost to exports is weaker when the exchange rate depreciation is associated with a banking crisis (short-dashed lines in Figure 8). In this case export prices decline by less, suggesting an average elasticity of export prices to the real effective exchange rate of 0.25 , about half of the baseline estimate. The response of real exports is near zero. Yet for a number of episodes associated with banking crises, some studies find that the effect on exports is rather positive - for example, the large depreciations of Argentina (2002), Brazil (1999), Russia (1998), and Sweden (1993).45

The results in this section suggest that trade responds substantially to exchange rates, with the response being the largest when there is slack in the economy and the financial sector is operating normally.

\section{Sector-Level Analysis}

This section estimates trade elasticities at the sector level. Estimating trade elasticities and their stability over time at the sector level has two advantages compared with estimating trade equations at the macroeconomic level. First, the estimation is less prone to reverse causality, as countries' exchange rate movements are less influenced by sector-level trade performances. Second, the estimates are less subject to aggregation bias. Both issues could confound the study of a possible disconnect between exchange rates and trade at the macroeconomic level. ${ }^{46,47}$

\footnotetext{
44 The list of episodes is available upon request. The results for such analysis are also robust to controlling for the occurrence of banking crises in trading partners in the estimated equations.

${ }^{45}$ For additional analysis of the effects of the 2002 Argentina episode, see Calvo, Izquierdo, and Talvi (2006). For the 1998 Russia episode, see Chiodo and Owyang (2002). For the 1993 Sweden episode, see Jonung (2010). See also IMF (2010).

46 Since Machlup (1950) and Orcutt (1950), the literature on estimation of trade elasticities has argued that elasticities estimated at the macro level may be biased downward. This downward bias has been recently emphasized again by Imbs and Mejean (2015). They show that with "well-behaved" residuals, a regression of aggregate imports on aggregate price of imports implies an estimate equal to a weighted average of microeconomic elasticities. With the sector-level heterogeneity in price elasticity of trade volume, the estimate is biased downward, as the aggregate price changes are largely accounted for by products with low elasticity. In this case, residuals correlate systematically with explanatory variables leading to the classic heterogeneity bias as defined by Pesaran and Smith (1995).

47 The aggregation bias implies that the change of the relative importance of sectors with low trade elasticities can lead to disproportionate changes in estimated macro-level trade elasticities.
} 
Using sector-level data enables additional analyses. First, the rich variation of GVC measures at the sector level allows us to investigate the relationship between GVC participation and trade elasticities (see Amiti, Itskhoki, and Konings 2014). Second, that a sector's share of a country's exports may change over time, and for some sectors that share may be large, enables us to test the importance of reverse causality between exchange rates and trade. This can be done by examining whether changes in sectors' share in a country's total exports affect trade elasticities.

Using sector-level data may also come at a cost, however. As Hillberry and Hummels (2013) point out, noise in trade price measures at the sector level bias the price elasticity of trade volume towards one. Therefore, we estimate the effects of exchange rate movements on trade volumes directly — a reduced form estimation of trade elasticities — rather than estimating the pass-through and price-to-volume elasticities separately.

\section{A. Data}

The main dataset used in this analysis is based on UN Comtrade database. To include GVC measures in our regression analysis, we employ data from the OECD TiVA database, which covers 46 countries, and restrict the sample period of this analysis to the years between 1995 and 2011.

The main challenges in assembling the sector-level dataset is to construct effective exchange rates that vary with sectors' destination profiles and price deflators that derive sectoral-level trade volumes from trade values. The UN Comtrade database provides export and import U.S. dollar values, and export and import quantities that allow us to construct product unit values. We aggregate each product unit value into one of 18 sector prices using the HS 2002 6-digit product classification system, based on the OECD Inter-Country Input-Output (ICIO) classification.

We construct import and export prices at the sector level as GEKS indexes (Ivancic, Diewert, and Fox 2011; and De Haan and van der Grient 2011), which are the geometric mean of the ratios of all bilateral indexes (computed with the same index number formula) between any two periods. The GEKS index has two advantages over the Fisher chain index on which it is based. First, it uses bilateral information between any two periods. This is useful because trade data at the product level often have gaps, creating issues for the construction of the Fisher chain index. Second, it avoids chain drift, which arises when a selection of goods used to compute an index changes significantly over time. Appendix $\mathrm{C}$ provides a detailed description of the index construction.

For calculation of the sector-level exchange rate, we use the Tornqvist method (Kee and Tang 2016). Its most important feature is that it includes only export destination countries to which exports went over two consecutive years. This method helps to avoid compositional bias. Mathematically, for the country pair i, j and sector $\mathrm{k}$, the sector-level exchange rate change from year $\mathrm{t}-1$ to year $\mathrm{t}$ is defined as: 


$$
=\sum_{j \in I_{k t}^{i} \cap I_{k t-1}^{i}} \frac{1}{\ln \left(E R_{k, t}^{i}\right)-\ln \left(E R_{k, t-1}^{i}\right)}\left(s_{j, k, t}^{i}+s_{j, k, t-1}^{i}\right)\left(\ln \left(E R_{j, t}^{i}\right)-\ln \left(E R_{j, t-1}^{i}\right)\right)
$$

where $I_{k t}^{i}$ is the set of countries that import from the sector $k$ of country $i$ in year $t ; s_{j, k, t}^{i}$ is the country $j$ 's share in the exports of sector $k$ of country $i ; \ln \left(E R_{j, t}^{i}\right)-\ln \left(E R_{j, t-1}^{i}\right)$ is the change of the bilateral exchange rate between country $i$ and $j$ from year $t-1$ to $t$.

We exclude outliers as observations with GEKS index changes above $90^{\text {th }}$ percentile and below the $10^{\text {th }}$ percentile of the distribution of price changes in the same industry, and in the same year.

\section{B. Sector-Level Estimations}

We estimate trade elasticities at the sectoral level using the following four equations:

$$
\begin{gathered}
\Delta \ln \left(\frac{e P^{X}}{P^{*}}\right)_{i k t}=\alpha_{i k}+\eta_{t}+\gamma_{\mathrm{k}} \Delta \ln \left(\frac{e P}{P^{*}}\right)_{i t}+\vec{\phi} \Delta \ln \left(\frac{e P}{P^{*}}\right)_{i k t} \times \vec{Z}_{i k t}+\beta_{t} \Delta \ln \left(\frac{U L C}{P^{*}}\right)_{i t}+v_{i k t}, \\
\Delta \ln X_{i k t}=\alpha_{i k}+\eta_{t}+\gamma_{\mathrm{k}} \Delta \ln \left(\frac{e P}{P^{*}}\right)_{i k t}+\vec{\phi} \Delta \ln \left(\frac{e P}{P^{*}}\right)_{i k t} \times \overrightarrow{\mathrm{Z}}_{i k t}+\beta_{t} \Delta \ln Y_{i t}^{*}+v_{i k t}, \\
\Delta \ln \left(\frac{e P^{M}}{P}\right)_{i k t}=\alpha_{i k}+\eta_{t}+\gamma_{k} \Delta \ln \left(\frac{e P}{P^{*}}\right)_{i t}+\vec{\phi} \Delta \ln \left(\frac{e P}{P^{*}}\right)_{i t} \times \overrightarrow{\mathrm{Z}}_{i k t}+\beta_{t} \Delta \ln Y_{i t}+v_{i k t}, \\
\Delta \ln M_{i k t}=\alpha_{i k}+\eta_{t}+\gamma_{k} \Delta \ln \left(\frac{e P}{P^{*}}\right)_{i t}+\vec{\phi} \Delta \ln \left(\frac{e P}{P^{*}}\right)_{i t} \times \overrightarrow{\mathrm{Z}}_{i k t}+\beta_{t} \Delta \ln Y_{i t}+v_{i k t},
\end{gathered}
$$

where $\alpha_{i k}$ denotes the country-industry fixed effects; and $\eta_{t}$ denotes the time fixed-effects; the real effective exchange rate's coefficient $\gamma_{k}$ is allowed to differ across industries; $\beta_{t}=\beta^{G F C}$ during the global financial crisis, defined as in year 2008 or 2009 , and otherwise is another constant. $\Delta \ln Y_{i t}$ is separated into two variables: real exports, and real domestic demand, defined as the sum of real consumption and real investment, to account for different import intensities of GDP components (Bussière et al. 2013, Morin and Schwellnus 2014). In turn, $\vec{Z}_{i k t}$ include a set of variables: (i) a period dummy that is equal to 1 for years after 2002, the middle of the sample period, and zero otherwise; (ii) a GVC-participation variable, measured by the foreign value-added share in exports at the country-sector- and the world- 
sector level; ${ }^{48}$ (iii) additional macroeconomic variables as controlled in Campa and Goldberg (2005), including the money supply growth rate, GDP growth, and inflation (their detailed definitions are found in the Table 7 notes); ${ }^{49}$ and (iv) a measure of sector $k$ 's share of country $i$ 's exports in year $t$. Except for the period dummy variable and the sectors' share in total exports, all other variables in $\vec{Z}_{i k t}$ are demeaned and further normalized by their standard deviation to facilitate the economic interpretation of their coefficients.

In equations (10) - (13), we assume that foreign and domestic demand have the same coefficients across sectors. This is true if the following two assumptions are satisfied. First, consumers have homothetic utility functions, or equivalently, their demands for final goods are linear in income. Second, firms have homothetic production functions, or equivalently, their demands for intermediate goods are proportional to the firm's total output.

\section{Results}

The results of exchange rate pass-through are presented in Table 7 and those of exchange rates' impact on trade volumes in Table 8 . We present three models which differ in relation to the set of variables included in $\vec{Z}_{i k t}$. First of all, model (1) only has the period dummy, which tests the overall stability of exchange rate effects on trade prices and volumes. Second, model (2) adds GVC measures and sectors' share in total exports to model (1) to study how GVC participation may affect trade elasticities, and how reverse causality may bias trade elasticity estimation. Finally, model (3) further adds macroeconomic variables controlled in Campa and Goldberg (2005) to model (2) to ensure that results in model (2) are not driven by omitted variable biases.

Several conclusions can be drawn from the results in Tables 7 and 8 . First, there is no consistent evidence from model (1) to support the claim that exchange rates and trade are disconnected over time. For three out of four trade elasticities, the hypothesis of stability over time in the relationship between exchange rates and trade cannot be rejected. Only for exchange rate effects on import volumes do our results show some decline over time. The earlier rolling regression results also show a decline in the price elasticity of import volumes at the end of the sample period. Our conjecture is that these are driven by the correlation

\footnotetext{
${ }^{48}$ Foreign value-added share at the world-sector level for a given sector equals the cross-country sum of valueadded in export divided by the cross-country sum of gross exports for the same sector.

${ }^{49}$ As discussed in Campa and Goldberg (2005), macroeconomic variables may explain cross-country differences in exchange rate pass-through. They include the relative stability of local monetary policy (see Devereux and Engel 2001), as exporters set their prices in the currency of the country that has the most stable monetary policies, import prices in local currency terms should be more stable in countries with more stable monetary policy. All else equal, exchange rate pass-through should be higher for countries with more volatile monetary policy. Country size may be another important factor in ranking pass-through elasticities. Exchange rate pass-through may be higher if the exporters are large in number relative to the presence of local competitors. One approximation to this notion is that a country's pass-through elasticity might be inversely related to real GDP. An alternative approach would be to also consider measures of sector-specific openness for countries.
} 
between domestic demands and exchange rate movements, which became more severe in recent years.

Second, there are no consistent patterns for how GVC participation impacts trade elasticities at the country and sector level. The effects of GVC participation on exchange rate passthrough is insignificant either statistically or economically. Columns (2) and (3) for exchange rate effects on export volumes (Table 8) suggest that sectors with higher shares of foreign value added in their exports are associated with weaker exchange rate effects on export volume. It is difficult to explain why the effects do not appear on the import side. Similarly, while Columns (2) and (3) for exchange rate effects on import volumes (Table 8) suggest that sectors with higher foreign value added in their world exports have seen to have stronger import elasticities, export elasticities are weaker. Because of the large sample, the insignificant and inconsistent results for the GVC variables are unlikely to be driven by noisy data, thus further refuting the claim that GVC participation significantly influences trade elasticities.

Finally, we find little evidence that industries with a larger share of a country's exports have smaller trade elasticities, as only the coefficients related to import volumes are significant. As we allow the coefficient of exchange rates to differ across industries in all specifications, these results should not be confounded by sectors' intrinsic differences. The findings suggest that reverse causality plays an insignificant role in driving trade elasticity estimates. As the trade equations and data sources in the sector-level analysis resemble those in the previous section that estimate macro-level trade elasticities, the rejection of any reverse causality significance provides assurance that the earlier results are robust. Overall, these results provide less support to the notion that GVC participation weakens the effects of exchange rate movements on trade than can be found in related work (Cheng and others, 2016, for example). One possible explanation is that we examine cross-sector average trade elasticities, which is close to the macroeconomic trade elasticity studied in earlier sections, while Cheng and others (2016) look at trade at a more granular level - trade in intermediate products used as inputs into other economies' exports. Understanding how GVC participation affects trade elasticities at the more granular level than at the macroeconomic level is beyond this paper, which we will leave for future research.

\section{Conclusion}

This paper finds little support for the view that exchange rates and trade have disconnected over time. There is scant evidence of a general weakening in the responsiveness of exports to relative export prices or in the effects of exchange rates on trade prices. These results are reached by examining the exchange rate pass-through to trade prices and the price elasticities of trade volumes separately. The results are robust across different types of analyses: rolling estimations of macro-level trade equations, a study of events with large currency depreciations, and Chow tests at the sector level.

We also find little evidence that GVC expansion has weakened trade elasticities over time. Little evidence of such a weakening emerges from our rolling estimates of macro-level 
equations within regions that witnessed greater GVC entrenchment; from Chow tests for countries that experienced a stronger increase in GVC participation; or from a sector-level analysis that interacts GVC participation measures with exchange rates. One explanation is that GVC-related trade has increased only gradually, with the bulk of global trade still consisting of conventional trade.

Based on our estimates at the macroeconomic level, we find that a 10 percent real effective depreciation in an economy's currency is associated with, on average, a 1.5 percent of GDP increase in real net exports, with substantial cross-country variation around this average (Figure 9). Through the study of large currency depreciation events, we also find that the effects of exchange rate depreciation on exports are stronger for those economies with economic slack and those whose financial systems are operating normally.

Our findings suggest that recent exchange rate movements should result in a substantial redistribution of real net exports across economies. ${ }^{50}$ As to direct effects on trade, the real effective exchange rate movements observed since January 2013 point to a redistribution of real net exports from the United States (and economies whose currencies move with the dollar) to the euro area, Japan, and to economies whose currencies move with the euro and the yen.

Policy considerations based on the traditional relationship between exchange rates and trade are thus still justifiable. The results confirm that exchange rate changes continue to have strong effects on export and import prices. This has implications for inflation dynamics and the transmission of monetary policy changes. Economies in which the rise of GVCs has weakened the effects of exchange rates on trade may have less scope for expenditure switching, and larger adjustments in exchange rates may be required to resolve trade imbalances. In general, however, the role of flexible exchange rates in facilitating the resolution of trade imbalances remains significant.

\footnotetext{
${ }^{50}$ Overall outcomes for trade will reflect not only the direct effect of exchange rates on trade, but also shifts in the underlying fundamentals driving exchange rates.
} 


\section{REFERENCES}

Ahmed, Swarnali, Maximiliano Appendino, and Michele Ruta. 2015. "Depreciations without Exports? Global Value Chains and the Exchange Rate Elasticity of Exports." World Bank Policy Research Working Paper 7390, World Bank, Washington.

— 2016. "Global Value Chains and the Exchange Rate Elasticity of Exports." $B E$ Journal of Macroeconomics, forthcoming.

Ahn, JaeBin, Mary Amiti, and David E. Weinstein. 2011. "Trade finance and the great trade collapse." American Economic Review 101 (3): 298-302.

Alessandria, George, Sangeeta Pratap, and Vivian Yue. 2013. "Export Dynamics in Large Devaluations.” International Finance Discussion Paper 1087, Board of Governors of the Federal Reserve System, Washington.

Alessandria, George, Joseph P. Kaboski, and Virgiliu Midrigan. 2010 "Inventories, Lumpy Trade, and Large Devaluations," American Economic Review 100: 2304-2339.

Amiti, Mary, Oleg Itskhoki, and Jozef Konings. 2014. "Importers, Exporters, and Exchange Rate Disconnect." American Economic Review 104 (7): 1942-78.

Andersen, Robert, 2008, Modern Methods for Robust Regression (Thousand Oaks, California: SAGE Publications).

Atkeson, Andrew, and Ariel Burstein. 2008. "Pricing-to-market, trade costs, and international relative prices." The American Economic Review 98, no. 5: 1998-2031.

Baum, Anja, Marcos Poplawski-Ribeiro, and Anke Weber. 2012. "Fiscal Multipliers and the State of the Economy" IMF Working Paper 12/286, International Monetary Fund, Washington.

Borensztein, Eduardo and José De Gregorio (1999), "Inflation and Devaluation after Currency Crises," mimeo, IMF.

Burstein, Ariel, and Gita Gopinath. 2014. "International Prices and Exchange Rates." In Handbook of International Economics, Vol. 4, edited by Gita Gopinath, Elhanan Helpman, and Kenneth Rogoff. Amsterdam: North-Holland.

Bussière, Matthieu, Giovanni Callegari, Fabio Ghironi, Giulia Sestieri, and Norihiko Yamano. 2013. "Estimating Trade Elasticities: Demand Composition and the Trade Collapse of 2008-2009." American Economic Journal: Macroeconomics Vol. 5 (3): 
$118-51$.

Bussière, Matthieu, Simona Delle Chiaie, and Tuomas A. Peltonen. 2014. "Exchange Rate Pass-Through in the Global Economy: The Role of Emerging Market Economies." IMF Economic Review 62: 146-78.

Bussière, Matthieu, Guillaume Gaulier, and Walter Steingress. 2016. "Global Trade Flows: Revisiting the Exchange Rate Elasticities.” Working Paper, Banque de France.

Calvo, Guillermo A., Alejandro Izquierdo, and Ernesto Talvi. 2006. "Phoenix Miracles in Emerging Markets: Recovering without Credit from Systemic Financial Crises." NBER Working Paper 12101, National Bureau of Economic Research, Cambridge, Massachusetts.

Campa, José Manuel, and Linda S. Goldberg. 2005. "Exchange Rate Pass-Through into Import Prices.” Review of Economics and Statistics 87 (4): 679-90.

Campa, José Manuel, and Linda S. Goldberg. 2008. "Pass-Through of Exchange Rates to Consumption Prices: What Has Changed and Why?" International Financial Issues in the Pacific Rim: Global Imbalances, Financial Liberalization, and Exchange Rate Policy (NBER-EASE Volume 17). University of Chicago Press. 139-176.

Cerra, Valerie, and Sweta Chaman Saxena. 2008. "Growth Dynamics: The Myth of Economic Recovery." American Economic Review 98 (1): 439-57.

Cheng, Kevin C., Gee Hee Hong, Dulani Seneviratne, and Rachel N. van Elkan. 2016. "Rethinking the Exchange Rate Impact on Trade in a World with Global Value Chains." International Economic Journal, forthcoming.

Chiodo, Abbigail J., and Michael T. Owyang, 2002. "A Case Study of a Currency Crisis: The Russian Default of 1998." Federal Reserve Bank of St. Louis Review (November/December): 7-18.

Constantinescu, Cristina, Aaditya Mattoo, and Michele Ruta. 2015. "The Global Trade Slowdown." In The Global Trade Slowdown: A New Normal? VoxEU.org eBook, edited by Bernard Hoekman. London: CEPR Press.

De Gregorio, José, 2016. "Large Depreciations: Recent Experience in Historical Perspective," Working Paper Series WP16-8, Peterson Institute for International Economics, Washington.

Dell'Ariccia, Giovanni, Enrica Detragiache, and Raghuram Rajan, 2005. “The Real Effect of 
Banking Crises.” IMF Working Paper 05/63, International Monetary Fund, Washington.

Devereux, Michael B., and Charles Engel, 2001. "Endogenous Currency of Price Setting in a Dynamic Open Economy Model,” NBER Working Papers 8559, National Bureau of Economic Research.

Duval, Romain, Kevin Cheng, Kum Hwa Oh, Richa Saraf, and Dulani Seneviratne. 2014. "Trade Integration and Business Cycle Synchronization: A Reappraisal with Focus on Asia.” IMF Working Paper 14/52, International Monetary Fund, Washington.

Feenstra, Robert C. 1994. "New Product Varieties and the Measurement of International Prices." American Economic Review, Vol. 84, No. 1, pp. 157-177.

Feenstra, Robert C., Joseph E. Gagnon, and Michael M. Knetter. 1996. "Market Share and Exchange Rate Pass-Through in World Automobile Trade." Journal of International Economics 40 (1-2): 187-207.

Feenstra, Robert C., Philip A. Luck, Maurice Obstfeld, and Katheryn N. Russ. 2014. "In Search of the Armington Elasticity." NBER Working Paper 20063, National Bureau of Economic Research, Cambridge, Massachusetts.

Frankel, Jeffrey, David Parsley, and Shang-Jin Wei. 2012. "Slow Pass-Through around the World: A New Import for Developing Countries?” Open Economies Review 23 (2): 213-51.

Frankel, Jeffrey A., and Andrew K. Rose. 1996. "Currency Crashes in Emerging Markets: An Empirical Treatment.” Journal of International Economics 41 (3-4): 351-66.

Goldfajn, Ilan, and Rodrigo Valdés (1999), “The Aftermath of Appreciations," Quarterly Journal of Economics, Vol. 114(1), pp. 229-262.

Goldstein, Morris, and Mohsin S. Khan. 1985. "Income and price effects in foreign trade." Handbook of international economics, Vol. 2, pp. 1041-1105.

Gopinath, Gita, Oleg Itskhoki, and Roberto Rigobon. 2010. "Currency Choice and Exchange Rate Pass-Through.” American Economic Review 100 (1): 304-36.

Gust, Christopher, Sylvain Leduc, and Robert Vigfusson. 2010. “Trade Integration, Competition, and the Decline in Exchange-Rate Pass-Through." Journal of Monetary Economics 57 (3): 309-24. 
Haan, Jan de, and Heymerik van der Grient. 2011. "Eliminating Chain Drift in Price Indexes Based on Scanner Data." Journal of Econometrics, Vol. 161 (1), pp. 36-46.

Hillberry, Russell, and David Hummels. 2013. "Chapter 18 - Trade Elasticity Parameters for a Computable General Equilibrium." Handbook of Computable General Equilibrium Modeling, Vol. 1, pp. 1213 - 1269.

Hoekman, Bernard, ed. 2015. The Global Trade Slowdown: A New Normal? VoxEU.org eBook. London: CEPR Press.

Iacovone, Leonardo, and Veronika Zavacka. 2009. "Banking Crises and Exports: Lessons from the Past." Policy Research Working Paper 5016, World Bank, Washington.

Imbs, Jean, and Isabelle Mejean. 2015. "Elasticity Optimism." American Economic Journal: Macroeconomics 7 (3), pp. 43-83.

International Monetary Fund (IMF). 2010. "Do Financial Crises Have Lasting Effects on Trade?” In IMF WEO October 2015 (Chapter 4), International Monetary Fund, Washington.

- 2015a. Ireland: 2015 Article IV Consultation—Staff Report. IMF Country Report 15/77, International Monetary Fund, Washington.

_ 2015b. "Global Value Chains: Where Are You? The Missing Link in Sub-Saharan Africa's Trade Integration.” In Regional Economic Outlook: Sub-Saharan Africa. Washington, April.

_ 2015c. "Reaping the Benefits from Global Value Chains." In Regional Economic Outlook: Asia and Pacific. Washington, April.

_. 2015d. "Singapore's Trade Elasticities: A Disaggregated Look into the Role of Global Value Chains and Complexity." In Singapore: Selected Issues, IMF Country Report 15/200, Washington.

_ 2015e. “Exchange Rates and Trade: Disconnect?" In IMF WEO October 2015 (Chapter 3), International Monetary Fund, Washington.

Ivancic, Lorraine, Erwin W. Diewert, and Kevin J. Fox. 2011. "Scanner data, time aggregation and the construction of price indexes." Journal of Econometrics, Vol. 161 (1), pp. 24-35.

Johnson, Robert C., and Guillermo Noguera. 2012. "Fragmentation and Trade in Value 
Added over Four Decades.” NBER Working Paper 18186, National Bureau of Economic Research, Cambridge, Massachusetts.

Jonung, Lars. 2010. "Lessons from the Nordic Financial Crisis." Paper presented at the 2011 American Economic Association meeting, Denver, Colorado, January 8.

Jordà, Òscar. 2005. "Estimation and Inference of Impulse Responses by Local Projections." American Economic Review 95 (1): 161-82.

Joy, Mark, Marek Rusnák, Kateřina Šmídková and Bořek Vašíček. 2015. "Banking and currency crises: differential diagnostics for developed countries," ECB Working Paper No. 1810, European Central Bank, Frankfurt.

Kee, Hiau Looi, and Heiwai Tang. 2016. "Domestic Value Added in Exports: Theory and Firm Evidence from China.” American Economic Review, forthcoming.

Kiendrebeogo, Youssouf. 2013. "How Do Banking Crises Affect Bilateral Exports?” IMF Working Paper 13/150, International Monetary Fund, Washington.

Krugman, Paul. 1986. "Pricing to Market When the Exchange Rate Changes.” NBER Working Paper 1926, National Bureau of Economic Research, Cambridge, Massachusetts.

1991. Has the Adjustment Process Worked? Policy Analyses in International Economics. Washington: Institute for International Economics.

—. 2015. "Strength Is Weakness.” New York Times, March 15, available at: http://www.nytimes.com/2015/03/13/opinion/paulkrugman- strength-isweakness.html?ref=todayspaper\&_r=0.

—. 2016. "The Return of Elasticity Pessimism.” New York Times, April 16, available at: http://krugman.blogs.nytimes.com/2016/04/16/the-return-of-elasticity-pessimismwonkish/? $\mathrm{r}=1$

Laeven, Luc, and Fabián Valencia. 2013. "Systemic Banking Crises Database.” IMF Economic Review 61 (2): 225-70.

Machlup, Fritz. 1950. "Elasticity Pessimism in International Trade.” Economia Internazionale. 3 (February 1950), pp. 118-141.

Milesi-Ferretti, Gian Maria, and Assaf Razin, 2002, "Current Account Reversals and Currency Crises: Empirical Regularities.” In Currency Crises, NBER Chapter, edited by Paul Krugman, 285-323. Chicago: University of Chicago Press. 
Morin, Myriam, and Cyrille Schwellnus. 2014. "An Update of the OECD International Trade Equations.” OECD Economics Department Working Paper 1129, Organisation for Economic Co-operation and Development, Paris.

Obstfeld, Maurice, and Kenneth Rogoff. 2007. "The Unsustainable U.S. Current Account Position Revisited." In G7 Current Account Imbalances: Sustainability and Adjustment, edited by Richard H. Clarida, 339-76. Chicago: University of Chicago Press.

Ollivaud, Patrice, Elena Rusticelli, and Cyrille Schwellnus. 2015. "The Changing Role of the Exchange Rate for Macroeconomic Adjustment." OECD Economics Department Working Paper 1190, Organisation for Economic Co-operation and Development, Paris.

Orcutt, Guy H. 1950. "Measurement of Price Elasticities in International Trade.” Review of Economics and Statistics 32 (2): 117-32.

Otani, Akira, Shigenori Shiratsuka, and Toyoichiro Shirota. 2003. "The Decline in the Exchange Rate Pass-Through: Evidence from Japanese Import Prices." Monetary and Economic Studies, Vol. 21(3), pp. 53-81.

Pedroni, Peter. 2004. "Panel Cointegration: Asymptotic and Finite Sample Properties of Pooled Time Series Tests with an Application to the PPP Hypothesis." Econometric Theory 20 (3): 597-625.

Pesaran, M. Hashem, and Ronald Smith. 1995. "Estimating Long-Run Relationships From Dynamic Heterogeneous Panels.” Journal of Econometrics, Vol. 68 (1), pp. 79-113.

Romer, Christina D., and David H. Romer. 2010. "The Macroeconomic Effects of Tax Changes: Estimates Based on a New Measure of Fiscal Shocks." American Economic Review 100 (3): 763-801.

Ronci, Marcio. 2004. "Trade Finance and Trade Flows: Panel Data Evidence from 10 Crises.” IMF Working Paper 04/225, International Monetary Fund, Washington. 


\section{TABLES AND FIGURES}

\section{Table 1 Economies Included in the Panel Estimation of Trade Elasticities}

Albania, Algeria, Argentina, Australia, Austria, Bangladesh, Belgium, Bolivia, Brazil, Bulgaria, Cambodia, Canada, Chile, China, Colombia, Republic of Congo, Costa Rica, Côte d'Ivoire, Croatia, Czech Republic, Denmark, Dominican Republic, Ecuador, Egypt, El Salvador, Estonia, Finland, France, Germany, Ghana, Greece, Guatemala, Honduras, Hungary, India, Indonesia, Iran, Israel, Italy, Japan, Jordan, Kenya, Korea, Kuwait, Kyrgyz Republic, Latvia, Lebanon, Libya, FYR Macedonia, Malaysia, Mexico, Morocco, Netherlands, New Zealand, Nicaragua, Nigeria, Norway, Oman, Pakistan, Paraguay, Peru, Philippines, Poland, Portugal, Romania, Russia, Saudi Arabia, Slovak Republic, Slovenia, South Africa, Spain, Sri Lanka, Sweden, Switzerland, Syria, Taiwan Province of China, Thailand, Trinidad and Tobago, Tunisia, Turkey, Ukraine, United Arab Emirates, United Kingdom, United States, Uruguay, Venezuela, Yemen, Zambia

\section{Table 2. Economies Included in the Individual Estimation of Trade Elasticities}

\begin{tabular}{|c|c|}
\hline Advanced Economies & Emerging Market Economies \\
\hline $\begin{array}{l}\text { Australia, Austria, Belgium, Canada, Denmark, Finland, } \\
\text { France, Germany, Greece, Israel, Italy, Japan, Korea, } \\
\text { Netherlands, New Zealand, Norway, Portugal, Spain, } \\
\text { Sweden, Switzerland, Taiwan Province of China, United } \\
\text { Kingdom, United States }\end{array}$ & $\begin{array}{l}\text { Algeria*, Argentina, Bangladesh, Bolivia*, Bulgaria, Chile*, } \\
\text { China, Colombia*, Republic of Congo*, Costa Rica, Côte } \\
\text { d'Ivoire*, Egypt, El Salvador, Guatemala, Honduras, Hungary, }^{*} \text {, India, Indonesia, Islamic Republic of Iran*, Jordan, Kenya, } \\
\text { Kuwait*, Malaysia, Mexico, Morocco, Nigeria*, Pakistan, } \\
\text { Paraguay*, Philippines, Saudi Arabia*, South Africa*, Sri } \\
\text { Lanka, Thailand, Trinidad and Tobago*, Tunisia, United Arab } \\
\text { Emirates, Venezuela* }\end{array}$ \\
\hline
\end{tabular}

* Denotes commodity exporters, that is, economies for which primary products constitute the main source of export earnings, exceeding 50 percent of total exports, on average, between 2009 and 2013. 
Table 3. Data Sources

\begin{tabular}{ll}
\hline Indicator & Source \\
\hline Export Prices & IMF staff calculations using export value divided by export volume \\
Export Volume & IMF, World Economic Outlook database \\
Export Value & IMF, World Economic Outlook database \\
Import Prices & IMF staff calculations using import value divided by import volume \\
Import Volume & IMF, World Economic Outlook database \\
Import Value & IMF, World Economic Outlook database \\
International Commodity Price & IMF, Global Assumptions database \\
Index & IMF, Global Assumptions database \\
International Energy Price Index & IMF, Information Notice System \\
Nominal Effective Exchange Rate & IMF, World Economic Outlook database \\
Nominal GDP & IMF, Information Notice System \\
Real Effective Exchange Rate & IMF, World Economic Outlook database \\
Real GDP & IMF staff calculations \\
Trade-Weighted Foreign CPI & IMF, Global Economic Environment database \\
Trade-Weighted Foreign Demand & IMF staff calculations \\
Trade-Weighted Foreign PPI & Organisation for Economic Co-operation and Development, \\
Unit Labor Cost ${ }^{1}$ & OECD Economic Outlook; U.S. Bureau of Labor Statistics; and \\
& IMF staff calculations \\
Indicators Used for Global Value Chain Analysis \\
Backward Participation & Organisation for Economic Co-operation and Development-World \\
& Trade Organization, Trade in Value Added database \\
Forward Participation & Organisation for Economic Co-operation and Development-World \\
& Trade Organization, Trade in Value Added database \\
\hline
\end{tabular}

Note: $\mathrm{CPI}=$ consumer price index; $\mathrm{PPI}=$ producer price index.

${ }^{1}$ IMF staff calculations use data from Haver Analytics; International Labor Organization; IMF, World Economic Outlook database; and IMF, International Financial Statistics. 


\section{Table 4. Exchange Rate Pass-Through and Price Elasticities}

\begin{tabular}{|c|c|c|c|c|c|}
\hline \multirow{3}{*}{$\begin{array}{l}\text { Based on Producer Price } \\
\text { Index } 2\end{array}$} & \multicolumn{2}{|c|}{$\begin{array}{l}\text { Exchange Rate Pass- } \\
\text { Through }\end{array}$} & \multicolumn{2}{|c|}{$\begin{array}{l}\text { Price Elasticity of } \\
\text { Volumes }\end{array}$} & \multirow{2}{*}{$\begin{array}{l}\text { Marshall-Lerner } \\
\text { Condition } \\
\text { Satisfied?1 }\end{array}$} \\
\hline & Export prices & $\begin{array}{l}\text { Import } \\
\text { prices }\end{array}$ & Exports & Imports & \\
\hline & & & & & \\
\hline Long-Term & 0.552 & -0.605 & -0.321 & -0.298 & Yes \\
\hline $\begin{array}{l}\text { One-Year Effect } \\
\text { Based on Consumer Price } \\
\text { Index }\end{array}$ & 0.625 & -0.580 & -0.260 & -0.258 & Yes \\
\hline Long-Term & 0.457 & -0.608 & -0.328 & -0.333 & Yes \\
\hline One-Year Effect & 0.599 & -0.546 & -0.200 & -0.200 & Yes \\
\hline \multicolumn{6}{|l|}{ Memorandum } \\
\hline \multicolumn{6}{|l|}{ Non-Commodity Exporters 4} \\
\hline Long-Term Elasticity ${ }^{2}$ & 0.571 & -0.582 & -0.461 & -0.272 & Yes \\
\hline
\end{tabular}

Source: IMF staff estimates.

Note: Table reports simple average of individual economy estimates for 60 economies during 1980-2014.

${ }^{1}$ The formula for the Marshall-Lerner condition adjusted for imperfect pass-through is

$\left(-E R P T\right.$ of $\left.P^{X}\right)(1+$ price elasticity of $X)+\left(E R P T\right.$ of $\left.P^{M}\right)(1+$ price elasticity of $M)+1>0$, in which $X$ denotes exports,

$M$ denotes imports, and $P^{X}$ and $P^{M}$ denote the prices of exports and imports, respectively (Annex 3.3).

2 Estimates based on producer price index-based real effective exchange rate and export and import prices relative to foreign and domestic producer prices, respectively.

${ }^{3}$ Estimates based on consumer price index-based real effective exchange rate and export and import prices relative to foreign and domestic consumer prices, respectively.

${ }^{4}$ Excludes economies for which primary products constitute the main source of export earnings, exceeding 50 percent of total exports, on average, between 2009 and 2013. 
Table 5. Trade Elasticities over Time: Stability Tests

\begin{tabular}{|c|c|c|c|c|}
\hline \multirow[b]{3}{*}{ By Region } & \multirow[t]{2}{*}{ Full } & 1990-2001 & 2002-2014 & $\begin{array}{c}\text { Statistical } \\
\text { Significance of the } \\
\text { Difference between } \\
\text { the Two Periods }{ }^{1}\end{array}$ \\
\hline & & \multicolumn{3}{|c|}{ 1. Pass-Through into Export Prices } \\
\hline & & & & \\
\hline All Countries & $0.569^{* * *}$ & $0.557^{\star * *}$ & $0.457^{* * *}$ & \\
\hline Asia & $0.429^{* * *}$ & $0.419^{* * *}$ & $0.346^{* * *}$ & \\
\hline Europe & $0.658^{* * *}$ & $0.647^{* * *}$ & $0.687^{* * *}$ & \\
\hline \multicolumn{5}{|c|}{ By Integration into Global Value Chains } \\
\hline Countries with Larger Increase & $0.572^{\star * *}$ & $0.560^{* * *}$ & $0.548^{* * *}$ & \\
\hline \multirow[t]{2}{*}{ Countries with Smaller Increase } & $0.684^{* * *}$ & $0.608^{* * *}$ & $0.609^{* * *}$ & \\
\hline & \multicolumn{4}{|c|}{ 2. Pass-Through into Import Prices } \\
\hline \multicolumn{5}{|l|}{ By Region } \\
\hline All Countries & $-0.612^{\star * *}$ & $-0.549^{\star \star *}$ & $-0.632^{\star \star *}$ & \\
\hline Asia & $-0.671^{* * *}$ & $-0.684^{* \star *}$ & $-0.668^{* * *}$ & \\
\hline Europe & $-0.553^{* * *}$ & $-0.528^{* * *}$ & $-0.587^{* * *}$ & \\
\hline \multicolumn{5}{|c|}{ By Integration into Global Value Chains } \\
\hline Countries with Larger Increase & $-0.621^{* * *}$ & $-0.545^{\star * *}$ & $-0.618^{* * *}$ & \\
\hline \multirow[t]{2}{*}{ Countries with Smaller Increase } & $-0.650^{* * *}$ & $-0.511^{* * *}$ & $-0.720^{\star * *}$ & ** \\
\hline & \multicolumn{4}{|c|}{ 3. Price Elasticities of Exports } \\
\hline \multicolumn{5}{|l|}{ By Region } \\
\hline All Countries & $-0.207^{* * *}$ & $-0.147^{\star \star *}$ & $-0.255^{\star * *}$ & * \\
\hline Asia & $-0.329^{* * *}$ & $-0.265^{\star * *}$ & $-0.489^{* * *}$ & ** \\
\hline Europe & $-0.281^{* * *}$ & $-0.303^{\star *}$ & $-0.375^{\star * *}$ & \\
\hline \multicolumn{5}{|c|}{ By Integration into Global Value Chains } \\
\hline Countries with Larger Increase & $-0.305^{\star * *}$ & $-0.343^{* *}$ & $-0.373^{\star * *}$ & \\
\hline \multirow[t]{2}{*}{ Countries with Smaller Increase } & $-0.402^{* * *}$ & -0.225 & $-0.566^{* * *}$ & * \\
\hline & \multicolumn{4}{|c|}{ 4. Price Elasticities of Imports } \\
\hline \multicolumn{5}{|l|}{ By Region } \\
\hline Asia & $-0.436^{* * *}$ & $-0.566^{\star * *}$ & -0.233 & \\
\hline Europe & $-0.470^{* * *}$ & $-0.484^{* * *}$ & $-0.446^{* * *}$ & \\
\hline \multicolumn{5}{|c|}{ By Integration into Global Value Chains } \\
\hline Countries with Larger Increase & $-0.521^{* * *}$ & $-0.658^{* * *}$ & $-0.271^{* *}$ & ** \\
\hline Countries with Smaller Increase & $-0.467^{* * *}$ & $-0.455^{\star * *}$ & $-0.420^{* * *}$ & \\
\hline
\end{tabular}

Source: IMF staff estimates.

${ }^{1}$ Blank space in this column indicates no statistically significant difference.

${ }^{*} p<0.1 ;{ }^{* *} p<0.05 ;{ }^{* * *} p<0.01$. 


\begin{tabular}{ll}
$\begin{array}{l}\text { Table 6. Large Exchange Rate Depreciations Not Associated with Banking } \\
\text { Crises }\end{array}$ \\
\hline Country & \multicolumn{1}{c}{ Advanced Economies } \\
\hline & 1985 \\
Australia & $1991,1993,2000$ \\
Greece & $1989,1993,2001$ \\
Iceland & 1993 \\
Ireland & 1989 \\
Israel & 1993 \\
Italy & 2008 \\
Korea & 1998,2000 \\
New Zealand & 1993 \\
Portugal & 1993,1997 \\
Spain & 1993 \\
United Kingdom &
\end{tabular}

\begin{tabular}{ll}
\hline & Emerging Market and Developing Economies \\
\hline Belarus & 2009 \\
China & 1994 \\
Comoros & 1994 \\
Ethiopia & 1993 \\
The Gambia & 1987 \\
Ghana & $2000,2009,2014$ \\
Guinea & 2005 \\
Haiti & 2003 \\
Honduras & 1990 \\
Iran, Islamic Republic of & $1985,1989,1993,2000,2002,2012$ \\
Kazakhstan & 1999 \\
Kiribati & 1985 \\
Libya & 2002,1998 \\
Madagascar & 2004 \\
Malawi & $1992,1994,1998,2003,2012$ \\
Mozambique & 2000 \\
Nepal & 1992 \\
Nigeria & 1999 \\
Pakistan & 2009 \\
Papua New Guinea & 1995,1998 \\
Paraguay & $1987,1989,2002$ \\
Poland & 2009 \\
Rwanda & 1991 \\
Solomon Islands & 1998,2002 \\
South Africa & 1984 \\
Syria & 1988 \\
Trinidad and Tobago & 1986,1993 \\
Turkmenistan & 2008 \\
Venezuela & $1987,2002,2009$ \\
Zambia & 2009 \\
\hline
\end{tabular}

Sources: Laeven and Valencia 2013; and authors' estimates.

CInternational Monetary Fund. Not for Redistribution 
Table 7. Estimates of Sector-Level Exchange Rate Pass-through

\begin{tabular}{|c|c|c|c|c|c|c|}
\hline \multirow[b]{2}{*}{ Variables $^{1}$} & \multicolumn{3}{|c|}{ Export price change } & \multicolumn{3}{|c|}{ Import price change } \\
\hline & $(1)$ & $(2)$ & (3) & $(1)$ & $(2)$ & (3) \\
\hline \multirow[t]{2}{*}{$\Delta \ln (\text { Exchange rate })^{2}$} & $0.360 * * *$ & 0.297 **** & $0.402^{\text {***** }}$ & $-0.717 * * *$ & $-0.633^{\text {***** }}$ & $-0.685^{* * *}$ \\
\hline & $(0.040)$ & $(0.050)$ & $(0.066)$ & $(0.026)$ & $(0.048)$ & $(0.062)$ \\
\hline \multirow[t]{2}{*}{$\Delta \ln ($ Exchange rate $) \times$ period dummy ${ }^{3}$} & 0.079 & $0.279^{* * * *}$ & 0.027 & $-0.109 * * *$ & -0.018 & -0.060 \\
\hline & $(0.042)$ & $(0.075)$ & $(0.104)$ & $(0.03)$ & $(0.071)$ & $(0.098)$ \\
\hline \multirow[t]{2}{*}{$\Delta \ln ($ Exchange rate $) \times$ money growth ${ }^{4}$} & & & -0.077 & & & 0.005 \\
\hline & & & $(0.08)$ & & & $(0.004)$ \\
\hline \multirow[t]{2}{*}{$\Delta \ln ($ Exchange rate $) \times$ real $\mathrm{GDP}^{5}$} & & & 0.006 & & & $0.0140^{* * *}$ \\
\hline & & & $(0.015)$ & & & $(0.005)$ \\
\hline \multirow[t]{2}{*}{$\Delta \ln ($ Exchange rate $) \times$ inflation rate ${ }^{6}$} & & & $-0.435^{* * *}$ & & & $0.0232 *$ \\
\hline & & & $(0.079)$ & & & $(0.013)$ \\
\hline \multirow{2}{*}{$\begin{array}{l}\Delta \ln (\text { Exchange rate }) \times \text { country-industry FVA share in } \\
\text { gros s exports }{ }^{7}\end{array}$} & & -0.020 & -0.027 & & $0.012 * * *$ & $0.013^{\text {***** }}$ \\
\hline & & $(0.035)$ & $(0.042)$ & & $(0.005)$ & $(0.006)$ \\
\hline \multirow{2}{*}{$\begin{array}{l}\Delta \ln (\text { Exchange rate }) \times \text { world industry FVA share in } \\
\text { gros s exports }{ }^{8}\end{array}$} & & $-0.274 * * *$ & 0.043 & & $0.030^{* * *}$ & $0.035^{\text {**ak }}$ \\
\hline & & $(0.099)$ & $(0.13)$ & & $(0.009)$ & $(0.010)$ \\
\hline \multirow[t]{2}{*}{$\Delta \ln ($ Exchange rate $) \times$ industry share in exports ${ }^{9}$} & & 0.038 & 0.038 & & $0.009^{* *}$ & 0.006 \\
\hline & & $(0.030)$ & $(0.031)$ & & $(0.004)$ & $(0.005)$ \\
\hline$\Delta \ln ($ Unit labor costs) & Yes & Yes & Yes & No & No & No \\
\hline $\begin{array}{l}\Delta \ln (\text { Sum of real consumption and real investment of } \\
\text { domestic economy) }\end{array}$ & No & No & No & Yes & Yes & Yes \\
\hline $\begin{array}{l}\Delta \ln (\text { Sum of real consumption and real investment of } \\
\text { domestic economy) } \times \text { GFC dummy }{ }^{10}\end{array}$ & No & No & No & Yes & Yes & Yes \\
\hline$\Delta \ln ($ Real exports of domestic economy) & No & No & No & Yes & Yes & Yes \\
\hline $\begin{array}{l}\Delta \ln (\text { Real exports of domestic economy }) \times \text { GFC } \\
\text { dummy }\end{array}$ & No & No & No & Yes & Yes & Yes \\
\hline Country and indus try fixed effects & Yes & Yes & Yes & Yes & Yes & Yes \\
\hline Time fixed effects & Yes & Yes & Yes & Yes & Yes & Yes \\
\hline Adjus ted R-s quared & 0.22 & 0.26 & 0.29 & 0.33 & 0.42 & 0.46 \\
\hline Number of obs ervations & 15,128 & 7,261 & 5,706 & 15,634 & 7,811 & 6,143 \\
\hline
\end{tabular}

Notes: Significance at ${ }^{* * *} \mathrm{p}<0.01,{ }^{* *} \mathrm{p}<0.05, * \mathrm{p}<0.1$. Standard errors are in the parentheses.

${ }^{1}$ This table reports estimated coefficients of equations (10) and (12).

${ }^{2}$ The average of sector-specific exchange rate coefficient $(\mathrm{Y})$.

${ }^{3}$ The period dummy is defined as 0 if the year is before 2002, and 1 otherwise.

${ }^{4}$ Money growth is defined as the annual growth rate of M2. For countries where M2 is not available, we use M1 instead, with the data from the IFS .

${ }^{5}$ Real GDP is defined as the annual growth rate of real GDP, with the data from the IMF WEO database.

${ }^{6}$ Inflation is defined as the annual CPI inflation, with the data from the IMF WEO database.

${ }^{7}$ Country-industry FVA share in gros s export is defined as the country and industry level bas ed on the OECD TiVA database.

${ }^{8}$ World industry FVA share is defined as the sum of foreign value added across all countries for the indus try, divided by the sum of export value for the industry. Data come from the OECD TiVAD and the UNCOMTRADE.

${ }^{9}$ Industry share in exports is defined as the export value of the industry in the country divided by the country's export value.

${ }^{10}$ The GFC dummy is 1 if the year is in 2008 or 2009 and 0 otherwise. 
Table 8. Estimates of Sector-Level Exchange Rate Effects on Trade Volume

\begin{tabular}{|c|c|c|c|c|c|c|}
\hline \multirow[b]{2}{*}{ Variables ${ }^{1}$} & \multicolumn{3}{|c|}{ Export volume change } & \multicolumn{3}{|c|}{ Import volume change } \\
\hline & (1) & (2) & (3) & (1) & (2) & (3) \\
\hline \multirow[t]{2}{*}{$\Delta \ln (\text { Exchange rate })^{2}$} & $-0.244 * * *$ & 0.217 & 0.221 & $1.147 * * *$ & $1.423 * * *$ & $1.829 * * *$ \\
\hline & $(0.124)$ & $(0.152)$ & $(0.184)$ & $(0.107)$ & $(0.147)$ & $(0.178)$ \\
\hline \multirow[t]{2}{*}{$\Delta \ln ($ Exchange rate $) \times$ period dummy ${ }^{3}$} & $-0.552^{* * * *}$ & $-0.949^{* * * *}$ & $-0.786^{* * *}$ & $-0.826^{\text {***** }}$ & $-1.634^{* * *}$ & $-1.604^{* * *}$ \\
\hline & $(0.133)$ & $(0.227)$ & $(0.277)$ & $(0.111)$ & $(0.226)$ & $(0.276)$ \\
\hline \multirow[t]{2}{*}{$\Delta \ln ($ Exchange rate $) \times$ money growth ${ }^{4}$} & & & $-1.246^{* * *}$ & & & 0.289 \\
\hline & & & $(0.253)$ & & & $(0.245)$ \\
\hline \multirow[t]{2}{*}{$\Delta \ln ($ Exchange rate $) \times$ real $\mathrm{GDP}^{5}$} & & & -0.098 & & & $-0.183^{* * *}$ \\
\hline & & & $(0.051)$ & & & $(0.048)$ \\
\hline \multirow[t]{2}{*}{$\Delta \ln ($ Exchange rate $) \times$ inflation rate ${ }^{6}$} & & & $1.552 * * *$ & & & $1.777 * * *$ \\
\hline & & & $(0.389)$ & & & $(0.305)$ \\
\hline \multirow{2}{*}{$\begin{array}{l}\Delta \ln (\text { Exchange rate }) \times \text { country-industry FVA share in } \\
\text { gros s exports }{ }^{7}\end{array}$} & & $0.320 * * *$ & $0.197^{\text {** }}$ & & 0.026 & 0.143 \\
\hline & & $(0.094)$ & $(0.104)$ & & $(0.081)$ & $(0.091)$ \\
\hline$\Delta \ln ($ Exchange rate $) \times$ world industry FVA share in & & 0.379 & 0.368 & & $1.427 * * *$ & $1.286 * * *$ \\
\hline gross exports $^{8}$ & & $(0.298)$ & $(0.377)$ & & $(0.281)$ & $(0.328)$ \\
\hline \multirow{2}{*}{$\Delta \ln ($ Exchange rate $) \times$ industry share in exports ${ }^{9}$} & & 0.051 & -0.013 & & 0.090 & $0.191^{* *}$ \\
\hline & & $(0.096)$ & $(0.103)$ & & $(0.097)$ & $(0.104)$ \\
\hline$\Delta \ln ($ Real trade weighted foreign GDP) & Yes & Yes & Yes & No & No & No \\
\hline $\begin{array}{l}\Delta \ln (\text { Sum of real consumption and real investment of } \\
\text { domestic economy) }\end{array}$ & No & No & No & Yes & Yes & Yes \\
\hline $\begin{array}{l}\Delta \ln (\text { Sum of real consumption and real investment of } \\
\text { domestic economy) } \times \text { GFC dummy }{ }^{10}\end{array}$ & No & No & No & Yes & Yes & Yes \\
\hline$\Delta \ln ($ Real exports of domestic economy) & No & No & No & Yes & Yes & Yes \\
\hline $\begin{array}{l}\Delta \ln (\text { Real exports of domestic economy) } \times \text { GFC } \\
\text { dummy }\end{array}$ & No & No & No & Yes & Yes & Yes \\
\hline Country and indus try fixed effects & Yes & Yes & Yes & Yes & Yes & Yes \\
\hline Time fixed effects & Yes & Yes & Yes & Yes & Yes & Yes \\
\hline Adjus ted R-s quared & 0.12 & 0.22 & 0.23 & 0.17 & 0.25 & 0.27 \\
\hline Number of obs ervations & 10,631 & 7,108 & 5,647 & 12,465 & 7,376 & 5,776 \\
\hline \multicolumn{7}{|c|}{ Notes: Significance at $* * * \mathrm{p}<0.01,{ }^{* *} \mathrm{p}<0.05, * \mathrm{p}<0.1 . \mathrm{S}$ tandard errors are in the parentheses. } \\
\hline \multicolumn{7}{|c|}{${ }^{1}$ This table reports estimated coefficients of equations (10) and (12). } \\
\hline \multicolumn{7}{|c|}{${ }^{2}$ The average of sector-specific exchange rate coefficient $(\mathrm{Y})$. } \\
\hline \multicolumn{7}{|c|}{${ }^{3}$ The period dummy is defined as 0 if the year is before 2002 , and 1 otherwise. } \\
\hline \multirow{2}{*}{\multicolumn{7}{|c|}{$\begin{array}{l}{ }^{4} \text { Money growth is defined as the annual growth rate of M2. For countries where M2 is not available, we use M1 ins tead, with the data from the IFS } \\
{ }^{5} \text { Real GDP is defined as the annual growth rate of real GDP, with the data from the IMF WEO database. }\end{array}$}} \\
\hline & & & & & & \\
\hline \multicolumn{7}{|c|}{${ }^{6}$ Inflation is defined as the annual CPI inflation, with the data from the IMF WEO database. } \\
\hline \multicolumn{7}{|c|}{${ }^{7}$ Country-industry FVA share in gross export is defined as the country and industry level bas ed on the OECD TiVA databas e. } \\
\hline \multirow{2}{*}{\multicolumn{7}{|c|}{$\begin{array}{l}{ }^{8} \text { World indus try FVA share is defined as the sum of fore ign value added across all countries for the indus try, divided by the sum of export value } \\
\text { for the indus try. Data come from the OECD TiVAD and the UNCOMTRADE. }\end{array}$}} \\
\hline & & & & & & \\
\hline \multicolumn{7}{|c|}{${ }^{9}$ Indus try share in exports is defined as the export value of the indus try in the country divided by the country's export value. } \\
\hline
\end{tabular}




\section{Figure 1. Recent Exchange Rate Movements in Historical Perspective}
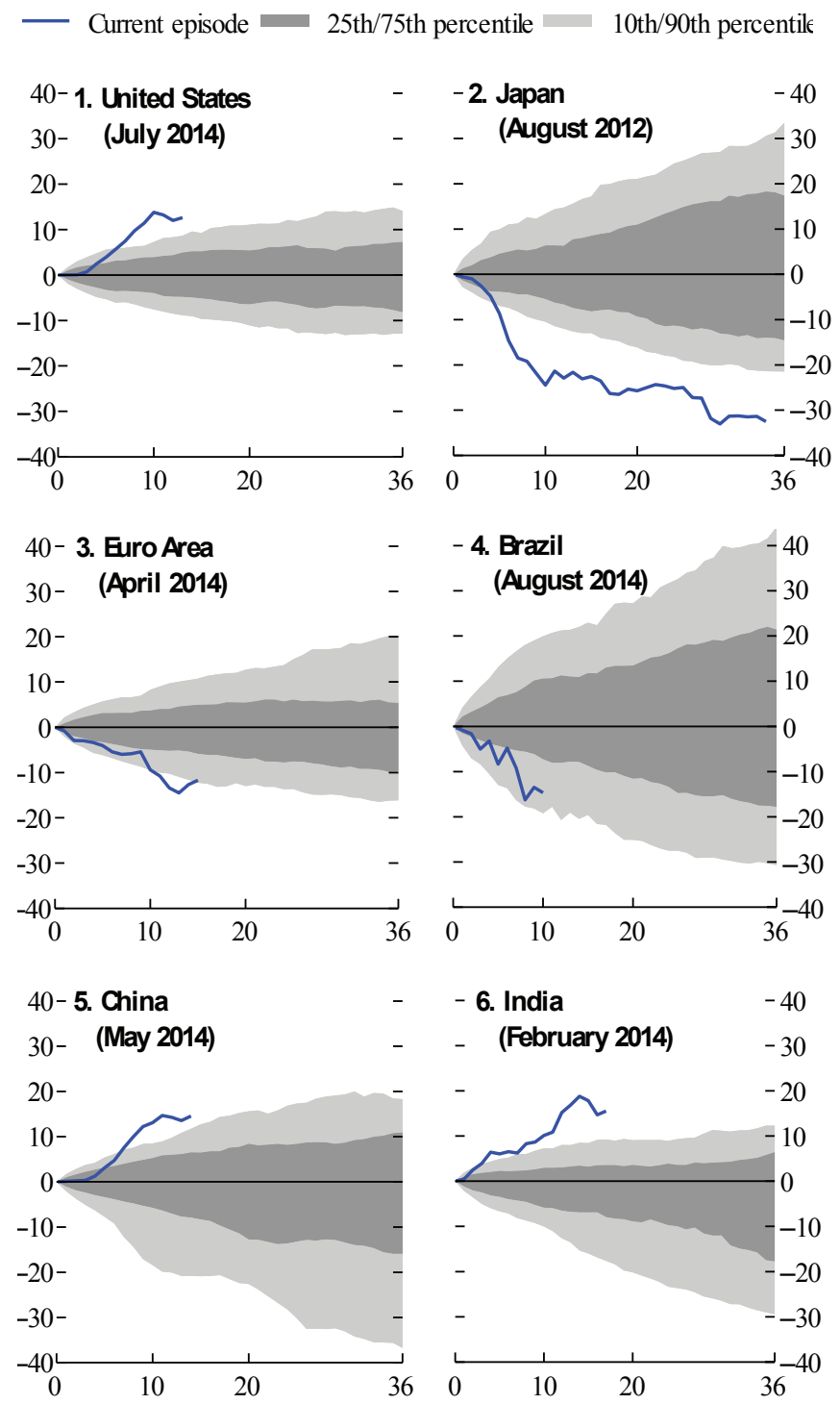

Source: $\mathbb{M}$, Information Notice System.

Note: Figure reports historical fluctuation bands for level of CPFbased real effective exchange rate based on all 36-month-long evolutions since January 1980. Confidence band at month $t$ is based on all historical evolutions up to month $t$. Blue lines indicate most recent exchange rate paths of appreciation or depreciation that have no interruptions of more than three months. Dates in parentheses mark the starting point for the current episode in each panel. Last observation reported is June 2015. 
Figure 2. Long-Term Exchange Rate Pass-Through and Price Elasticities
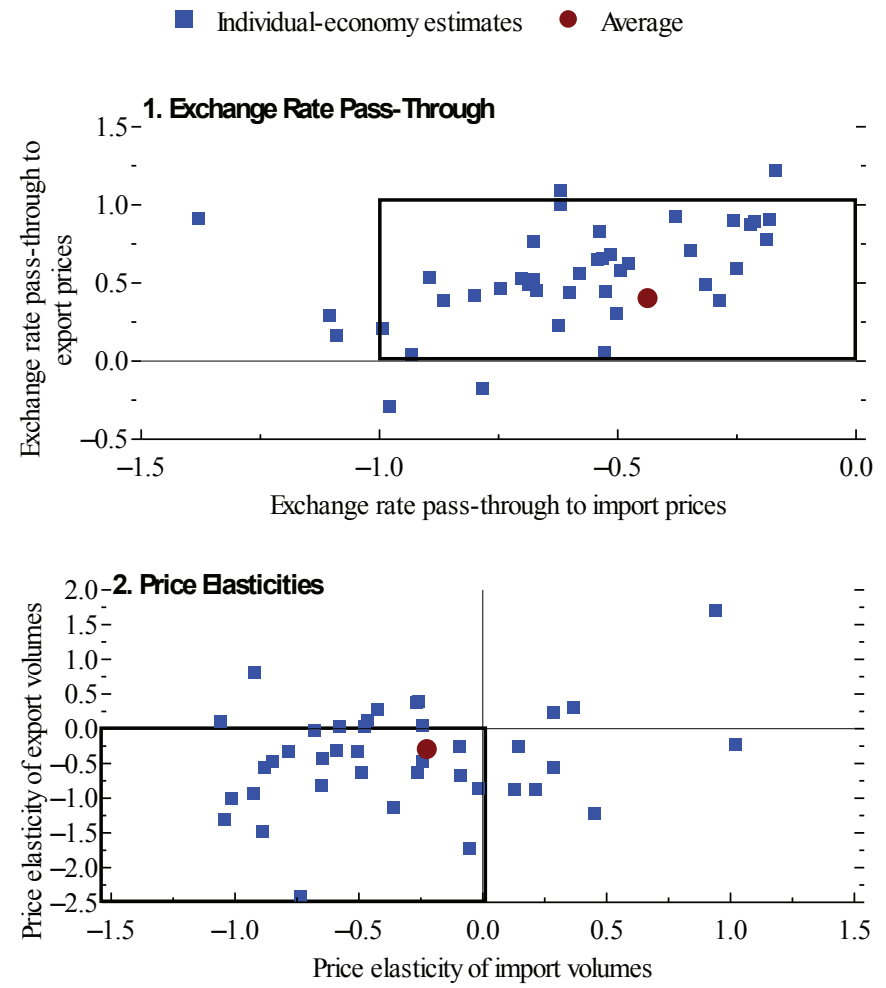

Source: $\mathbb{M F}$ staff estimates.

Note: Estimates based on annual data for 60 advanced and emerging market and developing economies from 1980 to 2014. Boxes indicate the expected sign and, in the case of exchange rate pass-through, the expected size of the estimates. 
Figure 3. Trade Elasticities over Time in Different Regions (Ten-year rolling windows ending in year t)

\section{Exchange Rate Pass-Through to Export Prices}

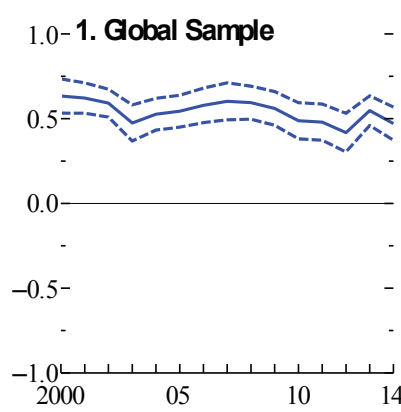

2. Asia

$-1.0$

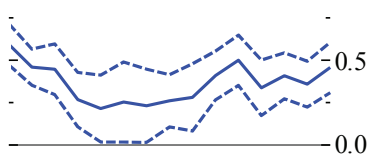

$--0.5$

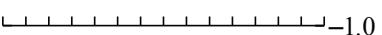

142000

Exchange Rate Pass-Through to Import Prices
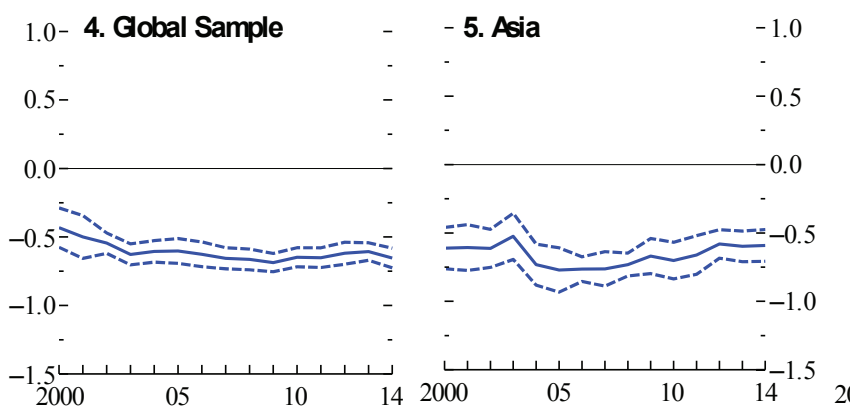

- 6. Europe

$-1.0$

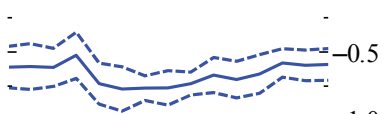

$--1.0$

- 3. Europe

$-1.0$
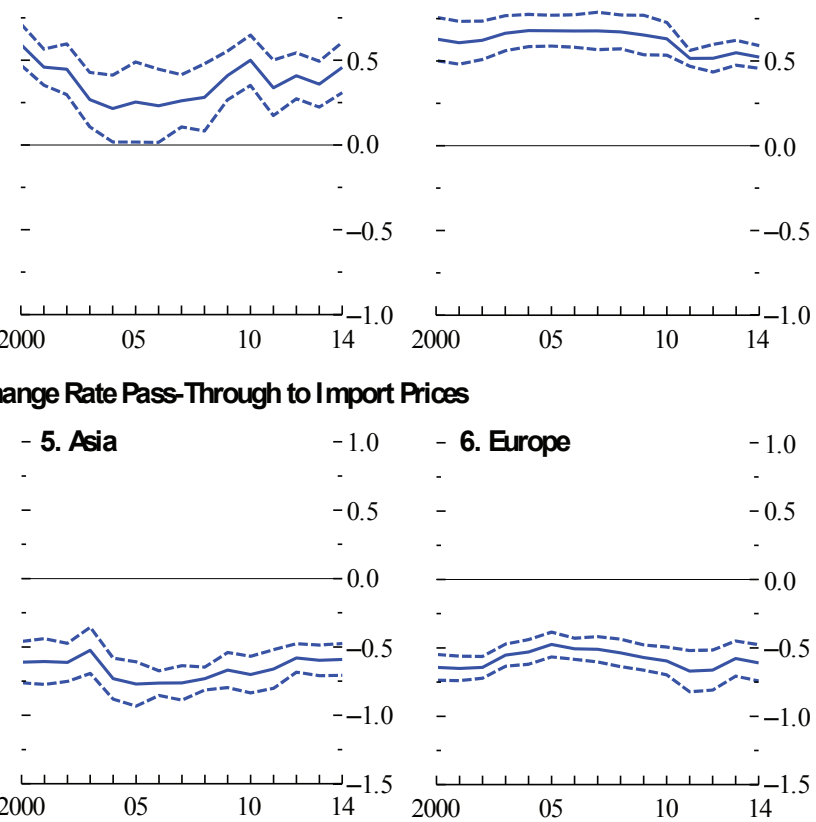

Price Basticities of Export Volumes

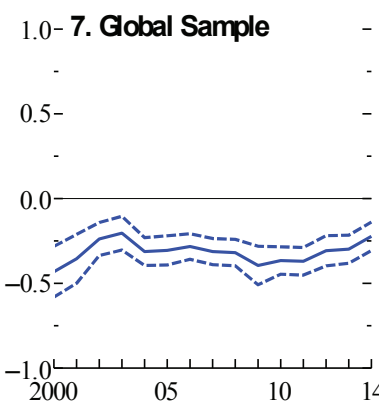

8. Asia

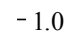

9. Europe

$-1.0$

$-0.5$

$-0.5$
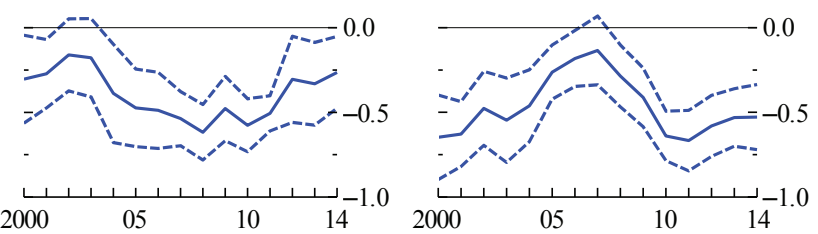

Price Basticities of Import Volumes

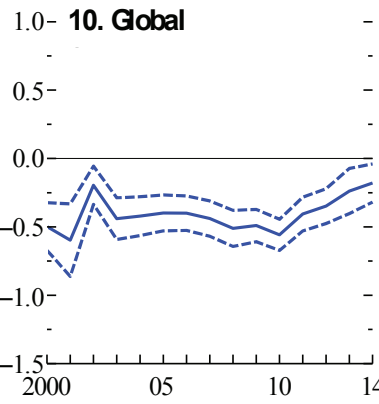

- 11. Asia

12. Europe -1.0
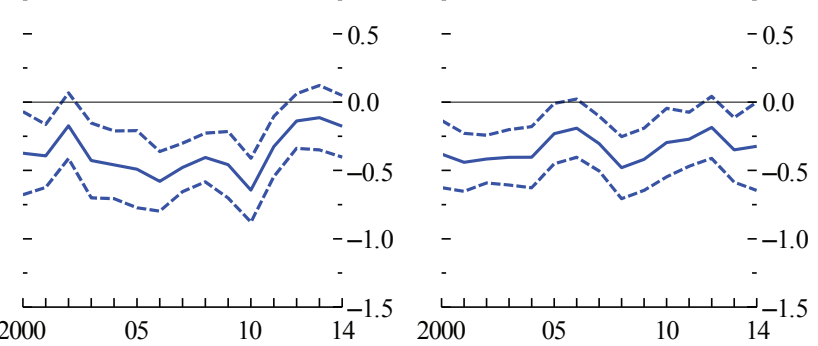

Source: $\mathbb{M F}$ staff estimates.

Note: Figure is based on panel estimates using producer price index-based real effective exchange rate and export and import prices relative to foreign and domestic producer prices, respectively. Full sample spans 88 advanced and emerging market and developing economies from 1990 to 2014. Dashed lines denote 90 percent confidence intervals. 
Figure 4. Evolution of Global Value Chains

1. Backward Participation 1
(Percent of gross exports)

100

- Johnson and Noguera 2012

- Duval and others 2014

80

$60-$

$40-$
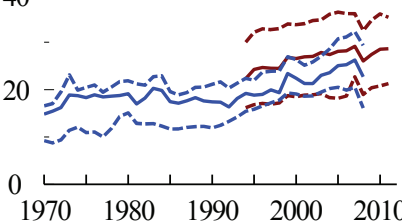

2. Forward Participation ${ }^{2}$ (Percent of gross exports)

$-40$
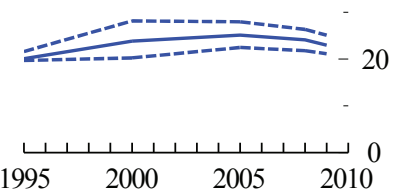

3. Change in Backward Participation 4. Change in Forward Participation (Percent; year of first observation to 2009) ${ }^{3}$ (Percent; year of first observation to 2009)
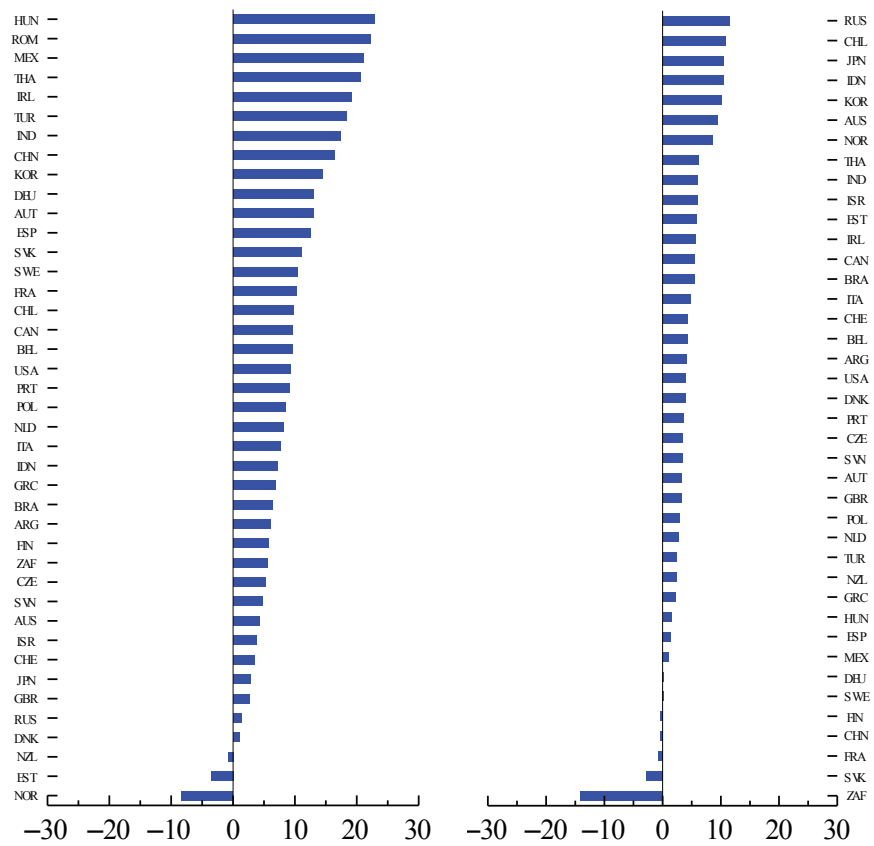

Sources: Duval and others 2014; Johnson and Noguera 2012; and Organisation for Economic Co-operation and Development.

Note: Data labels in the figure use International Organization for Standardization (ISO) country codes.

${ }^{1}$ Share of foreign value added in gross exports. Solid lines denote the average. Dashed lines denote 25th and 75th percentiles.

${ }^{2}$ Intermediate goods used by trading partners for production of their exports as a share of gross exports.

${ }^{3}$ Based on Johnson and Noguera 2012. 
Figure 5. Ratios of Exports and Imports to GDP, 1990-2014 (Percent)

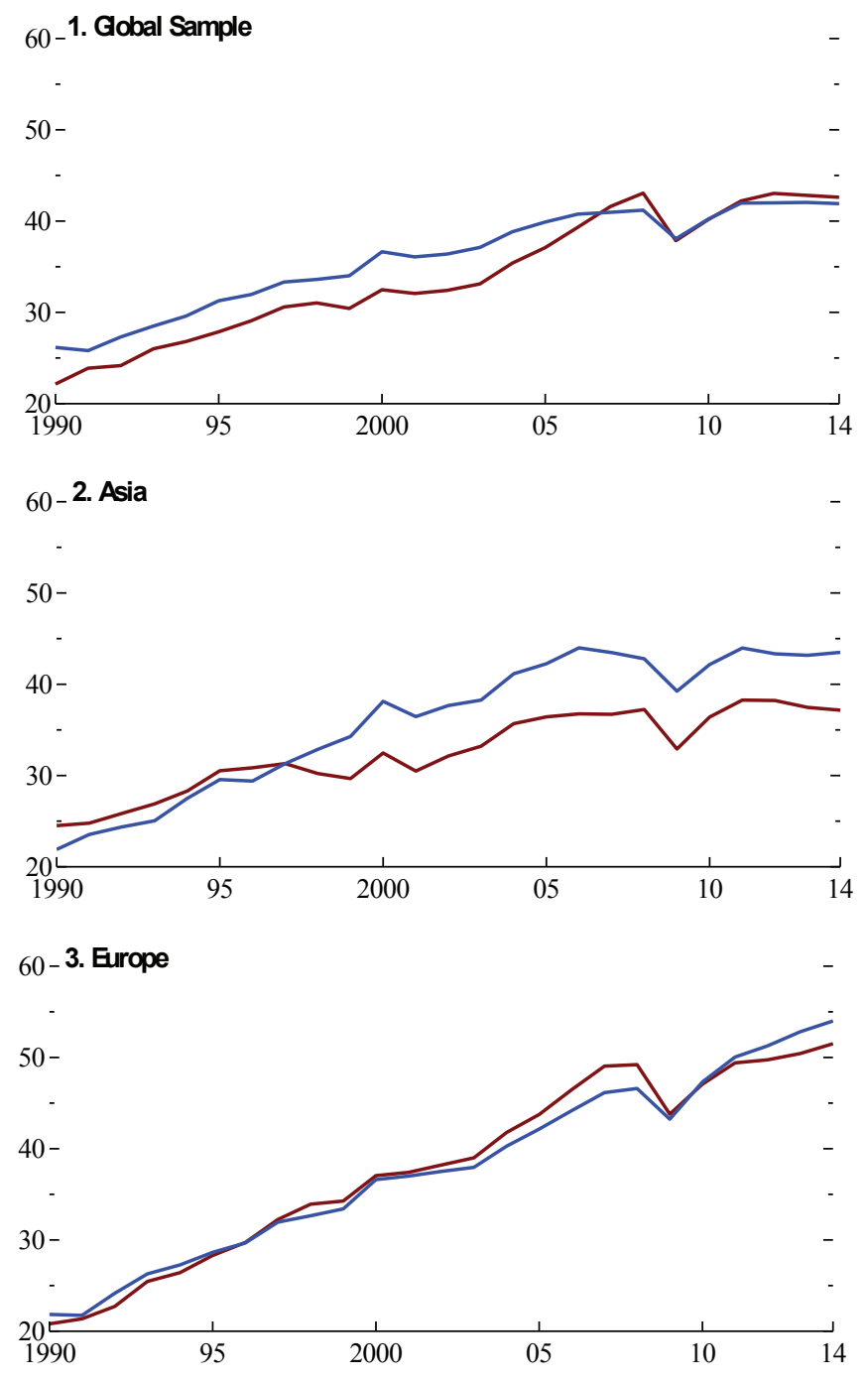

Source: IMF staff calculations.

Note: Figure presents simple averages of economies in the sample. 
Figure 6. Export Dynamics Following Large Exchange Rate Depreciations

(Percent; years on $x$-axis)
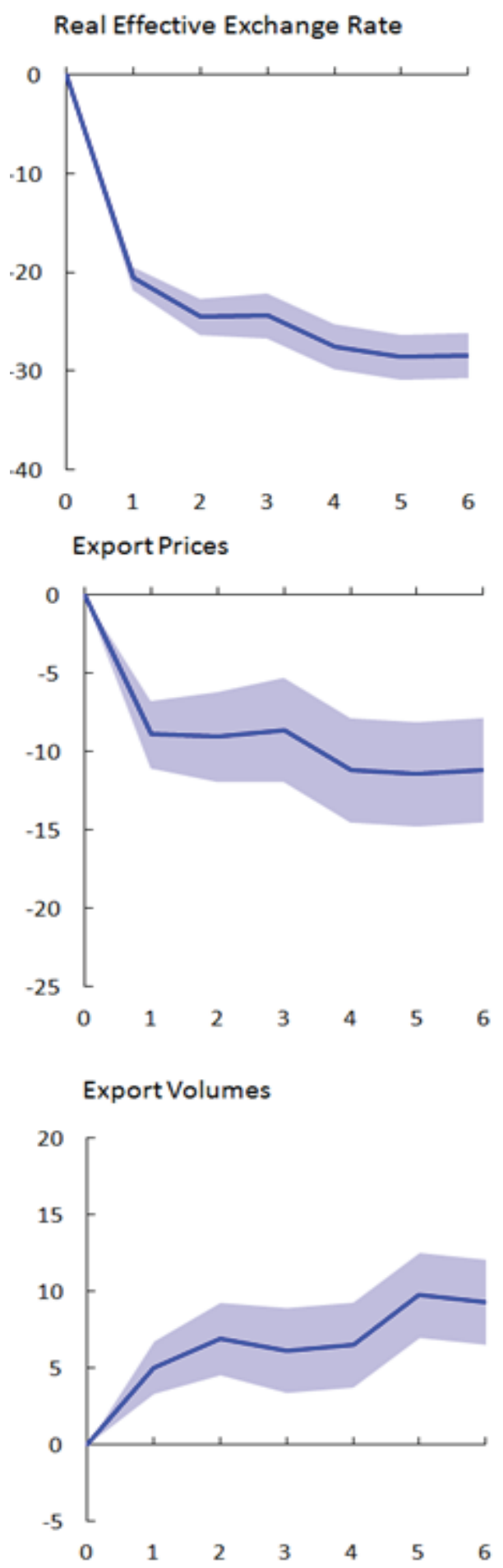

CInternational Monetary Fund. Not for Redistribution 
Figure 7. Export Dynamics Following Large Exchange Rate Depreciations: Through and After 1997

(Percent; years on $x$-axis)
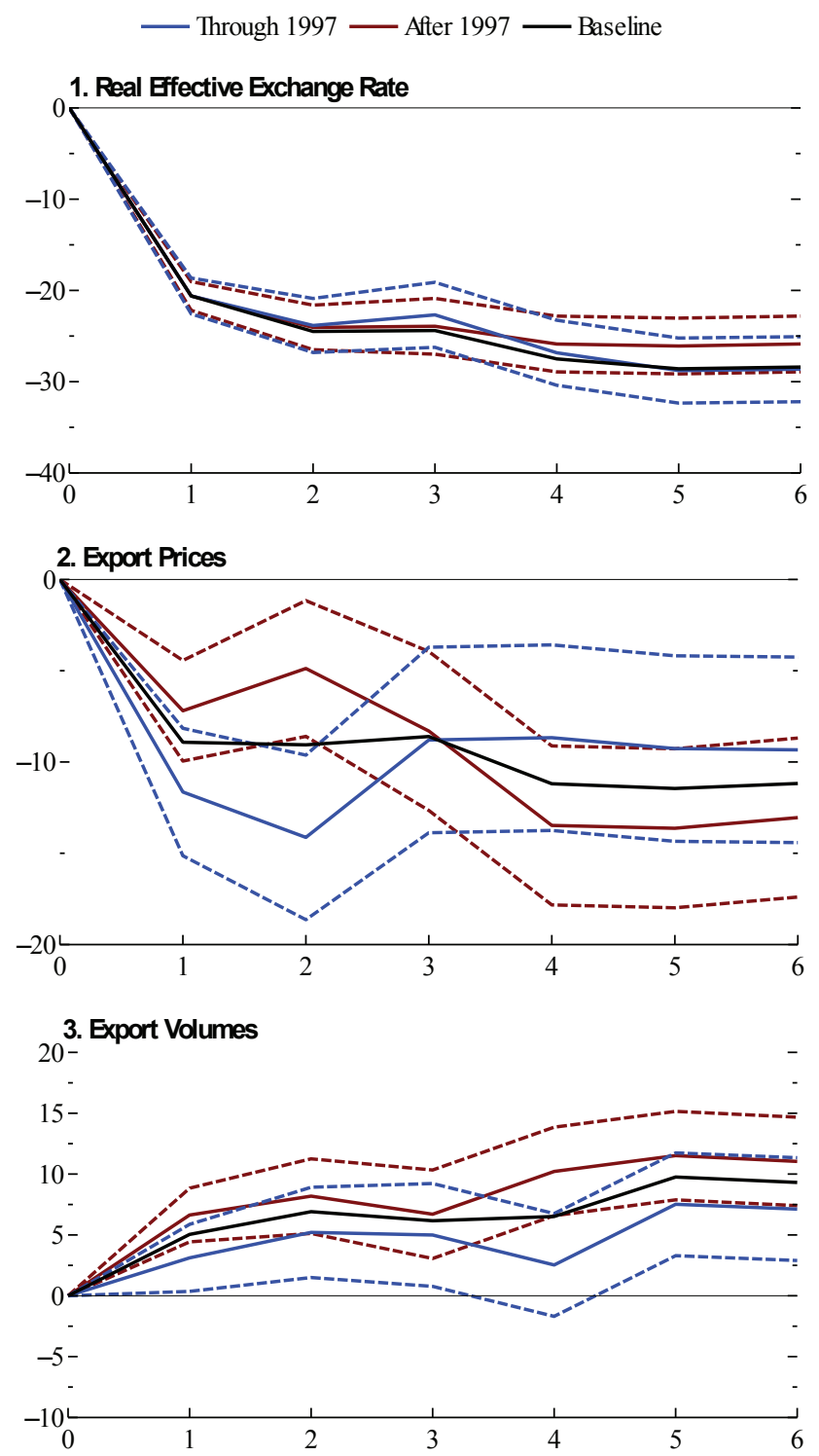

Source: $\mathbb{M}$ F staff estimates.

Note: Dashed lines denote 90 percent confidence intervals. 
Figure 8. Large Exchange Rate Depreciations: The Role of Initial Conditions (Percent; years on $x$-axis)
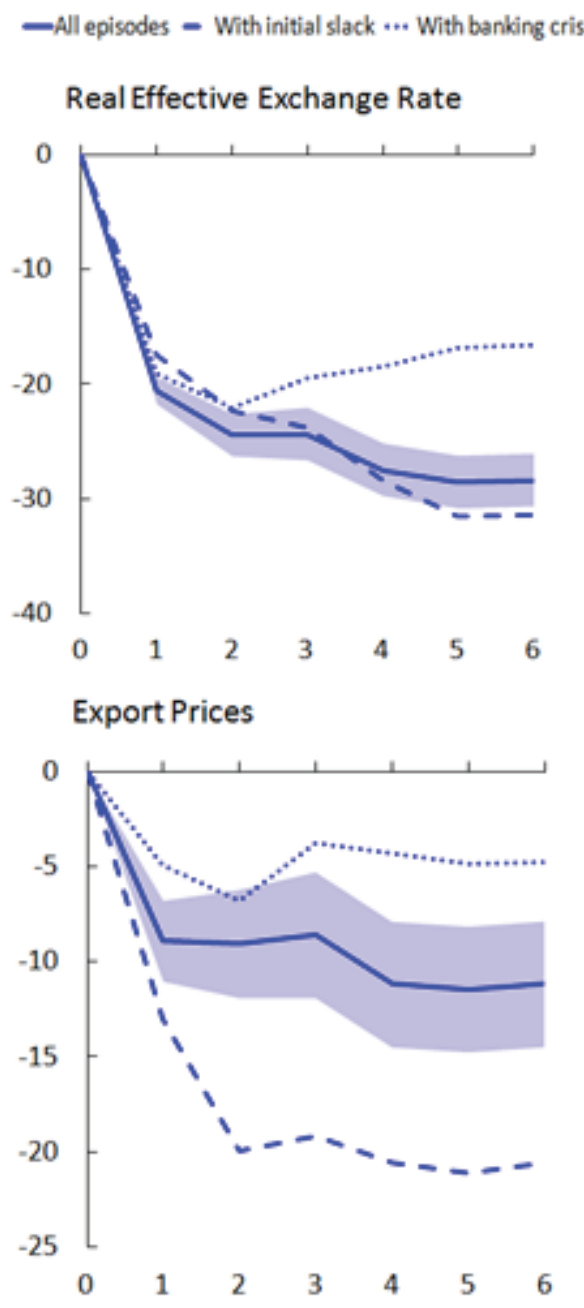

Export Volumes

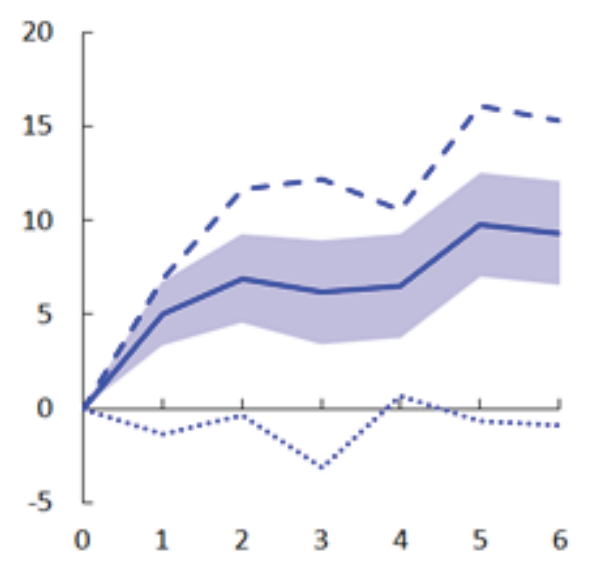

CInternational Monetary Fund. Not for Redistribution 
Figure 9. Effect of a 10 Percent Real Effective Depreciation on Real Net Exports

(Percent of GDP)

15

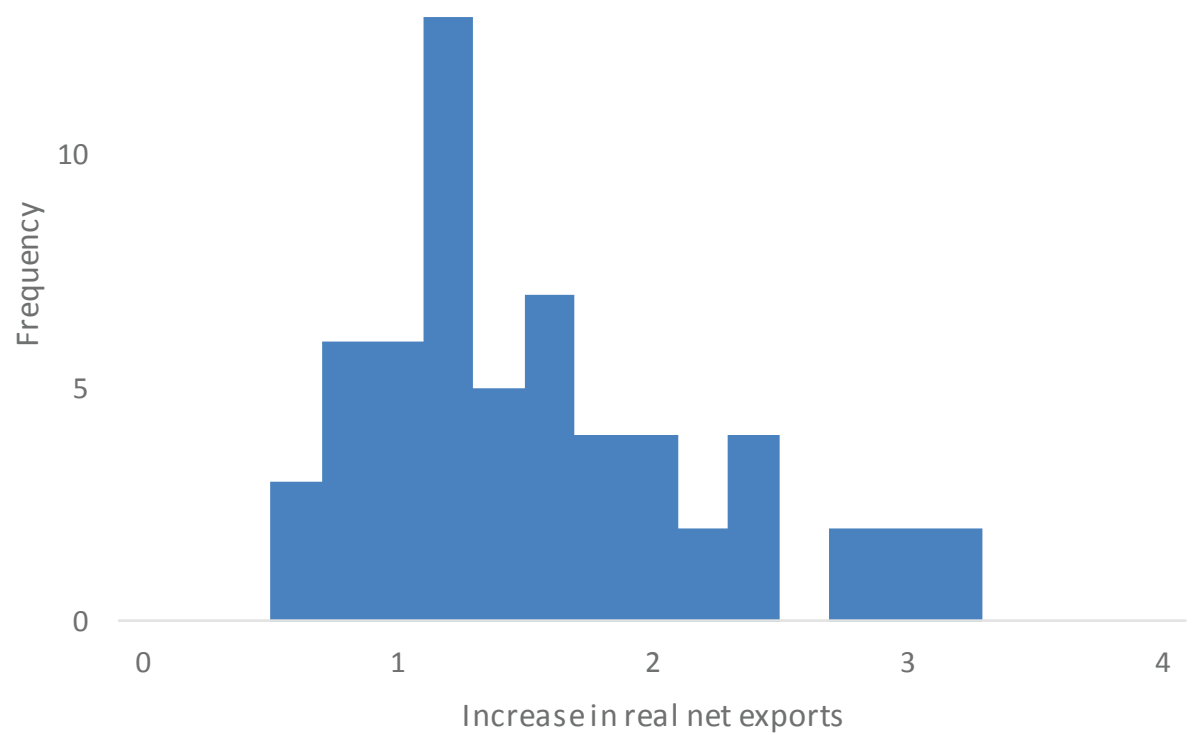

CInternational Monetary Fund. Not for Redistribution 


\section{APPENDIX \\ A. Country Samples}

Table A1. Economies Covered in the Trade in Value Added Database

Argentina, Australia, Austria, Belgium, Bulgaria, Brazil, Brunei Darussalam, Cambodia, Canada, Chile, China, Colombia, Costa Rica, Croatia, Cyprus, Czech Republic, Denmark, Estonia, Finland, France, Germany, Greece, Hong Kong SAR, Hungary, Iceland, Indonesia, India, Ireland, Israel, Italy, Japan, Korea, Latvia, Lithuania, Luxembourg, Malaysia, Malta, Mexico, Netherlands, New Zealand, Norway, Philippines, Poland, Portugal, Russia, Saudi Arabia, Singapore, Slovak Republic, Slovenia, South Africa, Spain, Sweden, Switzerland, Taiwan Province of China, Thailand, Tunisia, Turkey, United Kingdom, United States, Vietnam

Note: The Trade in Value Added database is from the Organisation for Economic Cooperation and Development and World Trade Organization.

Table A2. Economies Covered in the Sector-Level Analysis

Advanced economies Emerging economies

Aus tralia, Aus tria, Canada, Czech Republic, Algeria, Argentina, Bolivia, Brazil, Chile, China, Denmark, Finland, France, Germany, Greece, Colombia, Costa Rica, Croatia, Ecuador, Egypt, Italy, Japan, Korea, Latvia, Lithuania, Netherlands, Guatemala, Hungary, India, Indones ia, Macedonia, New Zealand, Norway, Portugal, S lovak Republic, FYR, Madagas car, Malays ia, Mauritius, Mexico, Slovenia, Spain, Sweden, S witzerland, United Morocco, Nicaragua, Oman, Paraguay, Peru, Kingdom, United States Romania, South Africa, Thailand, Trinidad and Tobago, Tunis ia, Turkey, Uruguay, Venezuela 


\section{B. Robustness Test: Exchange Rate to Export Volume Elasticity}

In this section we perform robustness tests on our estimations of trade elasticities. We examine how our results compare with a specification estimating the reduced form effect of exchange rates to export volumes, which is often used in the literature (for example, Ahmed, Appendino, and Ruta 2016). We estimate the following equation in a panel setup:

$$
\Delta X_{i, t}=\mu_{i}+\tau_{t}+\beta \Delta\left(\frac{e P}{P^{*}}\right)_{i t}+\gamma \Delta Y_{i, t}^{*}+\delta Y_{i, t-1}+\varepsilon_{i, t}
$$

where $\Delta X$ is the growth rate of either total real exports, real goods exports, or real manufacturing exports; ${ }^{51} \mu_{i}+\tau_{t} \mu_{i}+\tau_{t}$ are country- and time-fixed effects, respectively; $\frac{e P}{P^{*}}$ denotes a country's REER (here CPI-based); $\Delta Y_{i, t}^{*}$ is the growth rate of foreign (trading partner) GDP; and $Y$ is the (log) level of a country's real GDP in U.S. dollars.

Table 3 reports the results of estimating (14). ${ }^{52}$ For this analysis, we use the same period and country sample as in Ahmed, Appendino, and Ruta (2016), with 46 economies, spanning from 1996 to 2012. To test the robustness of our findings in relation to exchange rate-trade stability, we also split that sample, as they do, into two halves as do those authors (19962003 and 2004-2012).

Using that database and specification, we are able to closely replicate the findings of the literature. For total exports, we obtain a decline in the elasticity $(\beta)$ between the two subsamples from -1.2 to -0.7 and, for manufacturing exports from -1.3 to -0.6 .

We further investigate the robustness of these findings along three simple dimensions. First, we check whether outliers are driving the results. This is particularly the case because the period sample includes a number of financial crises and hyperinflations - Bulgaria in 1997 and Russia in 1999, among others. Since these episodes all occur in the early part of the sample, 1996-2003, they complicate the comparison of trade elasticities in this period and the later period, 2004-2012. Excluding the crises is thus warranted. Such episodes can also be created by factors that have an independent effect on trade, providing another reason for their exclusion.

The second row in Table 3 shows that reestimating (14) while excluding the 13 data points with CPI inflation in excess of 30 percent noticeably reduces the estimated decline in $\beta$. For

\footnotetext{
${ }^{51}$ We use three different specifications, one for each type of export product used in the left-hand side of (14).

52 Data for total exports and goods exports come from WEO. Data for manufacturing exports come from COMTRADE. Table 7 only reports the estimate of $\beta$ from (14). The estimates of the other coefficients are available upon request and similar to those obtained in the literature.
} 
example, for total exports, the decline is now from -0.8 to -0.7 (instead of from -1.2 to 0.7 ), while, for manufacturing exports, it is from -0.7 to -0.6 (instead of from -1.3 to -0.6 ). The estimated decline in $\beta$ is now inside one standard error of the estimate $(0.1)$.

To control for potential outliers, we additionally apply the robust regression approach to estimate (14). This econometric technique downweights observations with larger absolute residuals using iterative weighted least squares (Andersen 2008). The results displayed in the rows (3) in Table 3 underscore the fragility of the baseline results in Table 3 (rows (1)). For total exports, the estimated elasticity $\beta$ remains around -0.7 in the two subsamples in this table. For manufacturing exports, the point estimate of $\beta$ now rises in absolute value from 0.6 to -0.7 , although this change is again within one standard error of the estimate.

A second dimension of the robustness test performed to estimate (14) was to use the log of first-difference to calculate the growth rates of the variables, such as in (14), instead of percentage changes. Using percentage changes to calculate the growth rate of the variables introduces an asymmetry between increases and decreases - percentage increases are unbounded, whereas percentage decreases are bounded by -100 percent.

The results of estimating the reduced-form elasticity using this growth rate calculation are displayed in Row (4) in Table 3. Using the log first difference approach noticeably reduces the estimated decline in $\beta$. For example, for total exports, the decline is now from -0.8 to 0.6 (instead of from -1.2 to -0.7 ). For manufacturing exports, the decline in the estimate of $\beta$ is now from -0.8 to -0.7 , which is within one standard error of the estimate. This finding relates to the role of outliers, since taking log differences dampens the role of extreme values. The log difference specification is standard and consistent with the assumed log-linear model specification, so we maintain it for the remaining robustness checks.

In line with (4) and (6) to deflate export values and obtain the export volumes in foreign currency. The CPI reflects prices of many non-traded goods and services that do not relate to the cost structure of exports. Also, in the baseline specification of (14), the CPI deflator is used both, on the numerator of the REER variable on the right-hand side and in the denominator as the deflator of nominal exports on the left-hand side, implying a spurious strengthening of the negative comovement between trade volumes and the (CPI-based) REER. This issue holds in general, and specifically in the context of spikes in the CPI associated with high-inflation episodes. ${ }^{53}$

\footnotetext{
${ }^{53}$ More generally, the dynamics of export prices (especially of manufacturing goods) and the CPI are quite different. Even for an economy such as the United States with low inflation, the average difference in the growth rate of the CPI and the export deflator for goods over the period 1980-2014 is about 2.5 percentage points per year. So deflating exports with the CPI would imply a substantial difference in real export dynamics. A useful benchmark reference here is the OECD Economics Department working paper by Morin and Schwellnus 2014, which estimates trade elasticities based on export volumes for both AEs and EMDEs.
} 
When we deflate total exports using the deflator for total exports of goods and services, and deflate goods and manufacturing exports using the deflator for goods exports from WEO, the absolute size of the estimates of $\beta$ decline (Table 3, row 5). This result reflects the removal of the spurious correlation already mentioned. The estimated drop in $\beta$ is also less apparent. For total exports, the elasticity estimate is now unchanged at -0.2 across the two time subsamples, while the point estimates of $\beta$ for goods and manufacturing exports actually rise slightly (again within one standard error of the estimate). ${ }^{54}$

We also conduct an additional robustness check, removing the initial domestic GDP control from (14). This has little effect on our finding that the drop in $\beta$ over time is fragile. The conclusion is also not affected by expanding the sample from the 46 economies to the 88 economies included in Section II.D (see Table A3), or by expanding the time sample to span 1990-2014, instead of 1996-2012. Overall, the analysis in this section confirms our findings that there is no disconnect over time for trade elasticities at the macroeconomic level, even at its reduced form.

\footnotetext{
${ }^{54}$ When choosing the deflator for total exports of goods and services, one should be guided by economic theory and the effect of such choice on consistency of trade elasticity estimates. We believe that consistency of estimates takes precedence over accuracy. CPI is only a proxy for the correct export price index and its use is likely to result in biased estimates.
} 


\section{Table B1. Elasticity of Total Exports to the Real Effective Exchange Rate: Robustness Analysis}

Elasticity of Total Exports to the Real Effective Exchange Rate

\begin{tabular}{|c|c|c|c|}
\hline & Full sample & 1996-2003 & 2004-2012 \\
\hline (1) Baseline & $-1.046^{* * *}$ & $-1.245^{\star * \star}$ & $-0.664^{* * *}$ \\
\hline (2) As (1) but CPI inflation < 30\% & $-0.776^{* * *}$ & $-0.822^{* * *}$ & $-0.664^{* * *}$ \\
\hline (3) As (1) but without outliers (robust regression) 1/ & $-0.714^{* * *}$ & $-0.749^{* * *}$ & $-0.653^{* * *}$ \\
\hline (4) Log linear specification 2/ & $-0.734^{* * *}$ & $-0.780^{\star \star *}$ & $-0.633^{* * *}$ \\
\hline (5) As (4) but real exports defined using export prices (not CPI) & $-0.180^{* * *}$ & $-0.196^{\star *}$ & $-0.174^{* * *}$ \\
\hline (6) As (5) but no domestic real GDP control & $-0.177^{* * *}$ & $-0.186^{* *}$ & $-0.176^{* * *}$ \\
\hline
\end{tabular}

\section{Elasticity of Goods Exports to the Real Effective Exchange Rate}

(1) Baseline

\begin{tabular}{|c|c|c|}
\hline Full sample & 1996-2003 & 2004-2012 \\
\hline$-1.182^{* \star *}$ & $-1.440^{* * *}$ & $-0.622^{* * *}$ \\
\hline$-0.765^{\star \star \star}$ & $-0.804^{* * *}$ & $-0.622^{* * *}$ \\
\hline$-0.688^{* * *}$ & $-0.856^{* * *}$ & $-0.626^{* * *}$ \\
\hline$-0.814^{* * *}$ & $-0.861^{\text {*** }}$ & $-0.674^{* * *}$ \\
\hline$-0.157^{*}$ & -0.146 & $-0.169^{* * *}$ \\
\hline$-0.156^{* *}$ & -0.130 & $-0.192^{* * *}$ \\
\hline
\end{tabular}

Elasticity of Manufacturing Exports to the Real Effective Exchange Rate

\begin{tabular}{lccc}
\hline & Full sample & $1996-2003$ & $2004-2012$ \\
\cline { 2 - 4 } (1) Baseline & $-1.081^{* * *}$ & $-1.294^{* * *}$ & $-0.592^{* * *}$ \\
(2) As (1) but CPI inflation < 30\% & $-0.671^{* * *}$ & $-0.651^{* * *}$ & $-0.592^{* * *}$ \\
(3) As (1) but without outliers (robust regression) 1/ & $-0.691^{* * *}$ & $-0.592^{* * *}$ & $-0.653^{* * *}$ \\
(4) Log linear specification /2 & $-0.746^{* * *}$ & $-0.765^{* * *}$ & $-0.663^{* * *}$ \\
(5) As (4) but real exports defined using export prices (not CPI) & -0.0899 & -0.0377 & $-0.166^{*}$ \\
(6) As (5) but no domestic real GDP control & -0.0870 & -0.0160 & $-0.191^{* *}$ \\
\hline \hline & & \\
& \\
&
\end{tabular}

\section{Construction of the GEKS Indices}

We construct country-sector level export and import price indexes for 18 tradable sectors using UN Comtrade data at the annual frequency. The 18 sectors are defined in the text. We adopt a method proposed by Ivancic et al. (2011), which is an adapted version of the 
multilateral GEKS approach. The GEKS index has two properties: (1) it makes maximum use of all possible matches between any two periods, and (2) it has no chain drift.

To construct a price index for sector $i$ from the prices of products $n \in i$, for the period 0 to $\mathrm{M}$, we construct a GEKS price index, denoted as $G E K S_{0, t}$, with $t \in\{0, \ldots, M\}$. Hereafter, without confusion, we omit $i$ for simplicity. The construction consists of two steps. First, we obtain sector $i$-- GEKS price indexes for any two adjacent periods $\tau-1$ and $\tau$, denoted as $G E K S \tau-1, \tau$. Second, we calculate $G E K S_{0, t}$ using all $G E K S_{\tau-1, \tau}$ for $\tau=1, \ldots, \mathrm{t}$.

The details are as follows: in the first step, $G E K S_{\tau-1, \tau}$ is the geometric average of the ratios of bilateral Fisher indexes (defined below):

$$
G E K S_{\tau-1, \tau}=\prod_{l=0}^{M}\left(P_{\tau-1, l}^{F} / P_{\tau, l}^{F}\right)^{1 / M}=\prod_{l=0}^{M}\left(P_{\tau-1, l}^{F} \cdot P_{l, \tau}^{F}\right)^{1 / M}
$$

where $\mathrm{M}+1$ is the number of years, and $P_{\tau, l}^{F}$ denotes the Fisher index between period $\tau$ and $l$.

In the second step, the GEKS index between time 0 and time $t$ is defined as

$$
G E K S_{0, t}=\prod_{\tau=1}^{t}\left(G E K S_{\tau-1, \tau}\right)
$$

To construct the bilateral Fisher indices, $P_{F j, k}$ is defined as:

$$
\begin{gathered}
P_{j, k}^{F}=\sqrt{P_{j, k}^{L} * P_{j, k}^{P}} \\
P_{j, k}^{L}=\frac{\sum_{n}\left(P_{n, k} \cdot Q_{n, j}\right)}{\sum_{n}\left(P_{n, j} \cdot Q_{n, j}\right)} \\
P_{j, k}^{P}=\frac{\sum_{n}\left(P_{n, k} \cdot Q_{n, k}\right)}{\sum_{n}\left(P_{n, j} \cdot Q_{n, k}\right)}
\end{gathered}
$$

where $P_{j, k}^{L}$ is the Laspeyres price index, and $P_{j, k}^{P}$ the Paasche price index of sector $i$. Accordingly, the summation in these indexes is carried over products in sector $i$, with $P_{n, t}$ indicating the price, and $Q_{n, t}$ the quatity of product $n$ in year $t$. Products are defined at the HS 2002 6-digit level. 